\title{
Öğretmenlerin Duygusal Emek Gösterimleri İle Psikolojik Sözleşmeye Uyma Düzeyleri Arasındaki İlişki ${ }^{1}$
}

DOI: $10.26466 /$ opus. 860699

\author{
Süleyman Sirrı Aydoğan* - $\underline{\text { Aynur B.Bostanc1 }}{ }^{* *}$ \\ *Okul MüdürYrd., Yüksek Lisans. Kütahya /Türkiye \\ E-Posta: slymn1984@gmail.com \\ ORCID: $\underline{0000-0001-6162-2573}$ \\ **Doç. Dr., Uşak Üniversitesi, Eğitim Fakültesi, Uşak/Türkiye \\ E-Posta: aynur.bozkurt@usak.edu.tr \\ ORCID: $\underline{0000-0002-7927-6063}$
}

\section{Öz}

$B u$ araştırma, öğretmenlerin duygusal emek gösterimleri ile psikolojik sözleşmeye uyma düzeyleri arasındaki ilişkiyi belirlemek amacıyla yapılmıştır. Araştırma ilişkisel tarama modeli ile desenlenmiştir. Araştırma evreni, 2019-2020 eğitim öğretim yılında Kütahya'nın Gediz, Simav, Şaphane ve Çavdarhisar ilçelerindeki kamu okullarında çalışan 1502 öğretmenden oluşmaktadır. Araştırmanın örneklemi ise, kolay ulaşılabilir örneklemeyle seçilen 405 öğretmendir. Araştırmada veriler "Duygusal Emek Ölçeği" ve "Psikolojik Sözleşmeye Uyma Düzeyi Ölçeği" ile toplanmıştır. Araştırma verileri tTesti, Tek Yönlü Varyans Analizi (ANOVA), Pearson Momentler Çarpımı Korelasyonu ve Çoklu Regresyon Analizi ile analiz edilmiştir. Araştırmanın sonuçlarına göre; öğretmenlerin duygusal emek gösterimleri yüzeysel rol yapmada düşük, derinden rol yapmada yüksek ve doğal duygularda çok yüksektir. Yine öğretmenlerin duygusal emek gösterimleri cinsiyetlerine göre farkllaşırken, çalıştıklar okul düzeyine, kıdemlerine, eğitim durumlarına, okuldaki öğretmen sayısına ve ayn okulda çalışma sürelerine yönelik farklılaşmamaktadır. Öğretmenlerin psikolojik sözleşmeye uyma düzeyleri yüksektir. Öğretmenlerin psikolojik sözleşmeye uyma düzeyleri çalıştıkları okul düzeyine, cinsiyetlerine ve kıdemlerine göre farklılaşırken; mezuniyet durumlarına, çalıştıkları okuldaki öğretmen sayısına ve ayn okulda çalışma sürelerine göre farklılaşmamaktadır. Öğretmenlerin psikolojik sözleşmeye uyma düzeyleri ile yüzeysel rol yapma gösterimleri arasinda negatif yönlü ve düşük; derinden rol yapma gösterimleri ile pozitif yönlü ve düşük; doğal duygular gösterimleri ile pozitif yönlü ve orta düzeyde ilişkilerin varlığına rastlanmıştır. Öğretmenlerin derinden rol yapma ve doğal duygu gösterimleri psikolojik sözleşmeye uyma düzeylerini yordamaktadır.

Anahtar Kelimeler: Duygu gösterimi, psikolojik sözleşme, yüzeysel rol yapma, derinden rol yapma.

\footnotetext{
${ }^{1}$ Bu makale, Uşak Üniversitesi Lisansüstü Eğitim Enstitüsü'nde ikinci yazarın danışmanlığında yürütülen aynı konulu yüksek lisans tezinden üretilmiştir.
} 


\title{
The Relationship between Teachers' Demonstrations of Emotional Labour and Their Level of Adherence to the Psychological Contract
}

\begin{abstract}
This research is made to determine the relationship between teachers' demonstrations of emotional labour and their level of adherence to the psychological contract. The research is designed with the relational survey model. The research population consists of 1502 teachers working in public schools in the districts of Gediz, Simav, Şaphane and Çavdarhisar in Kütahya in the 2019-2020 academic year. The sample of the study is 405 teachers selected with convenience sampling method. The research data have been collected with, "Emotional Labour Scale" "Level of Adherence to the Psychological Contract Scale". Research data are analysed by One-Way Analysis of Variance (ANOVA), Independent Samples t-Test, Pearson Product-Moment Correlation and Multiple Regression Analysis. According to the results of the research, the perception levels of teachers towards the demonstrations of emotional labour are low in surface acting, high in deep acting and very high in genuine emotions. While teachers' demonstrations of emotional labour differ according to their gender, they do not differ in terms of their school level, seniority, education level, number of teachers at their school and the duration of their employment in the same school. Teachers' perception level towards adherence to the psychological contract is high. While teachers' level of adherence to the psychological contract differs according to their school level, gender and seniority; it does not differ according to their graduation status, the number of teachers at the school they work and the duration of their employment in the same school. There is a low and negative correlation between teachers' surface acting demonstrations and their level of adherence to the psychological contract. There is a positive and low level of correlation between teachers' demonstrations of deep acting and their level of adherence to the psychological contract. There is a positive and medium level of correlation between teachers' demonstrations of genuine emotions and their level of adherence to the psychological contract. Teachers' deep acting and genuine emotion demonstrations can significantly explicate their level of adherence to the psychological contract.
\end{abstract}

Keywords: Emotion demonstration, psychological contract, surface acting, deep acting 


\section{Giriş}

Çalışma yaşamında gerçekleşen hızlı değişimler, örgütlerin hizmet sunumlarında kişilerarası iletişim ve etkileşimini önemsemelerine yol açmıştır. Bu yüzden çalışanlardan, hizmet alanlara yönelik doğru tutum ve davranış içerisine girmeleri, fiziksel ve zihinsel emeklerinin yanında duygusal emek te harcamaları beklenmektedir (Güngör Delen, 2017; Eroğlu, 2014). Okullar da yüz yüze iletişim ve etkileşimin en sık yaşandığı kurumların başında gelmektedir. Dolayısı ile öğretmenler sürekli olarak duygularını düzenlemeye çaba göstermekte, zihinsel ve fiziksel emeklerinin yanı sıra duygusal olarak da emek harcamaktadırlar (Tozkoparan ve Özgün, 2015). Öğretmenlik mesleği, duygusal emek konusunda en yüksek gerekliliklere sahip mesleklerin başında gelmektedir (Truta, 2014). Öğretmen duygusu üzerine yapılan tüm çalışmalar duyguların öğretmenlerin yaşamlarıyla ayrılmaz bir şekilde bağlantılı olduğu konusunda fikir birliğindedirler (Yin, Lee, Zhang ve Jin, 2013; Zembylas, 2004). Öğretmenlik mesleğinde paydaşlarla (öğrenci, veli, yönetici, iş arkadaşları) olan yoğun yüz yüze etkileşimler, okul yönetiminin beklentileri, çevrenin kültürel beklentiler ve mesleki normlar duygusal emek gösterimlerini zorunlu kilmaktadır (Winograd, 2003). Bununla birlikte çalışanlarda, örgütlerinin kendilerinden beklediği görev ve sorumluluklarına yönelik harcadıkları zihinsel ve duygusal emeklerinin karşılığında, kurumlarından bazı beklentiler içerisine girmektedirler. Yani hem örgütün hem de çalışanların karşılıklı beklentilerinin bütünü psikolojik sözleşme olarak adlandırılmaktadır (Doğan ve Demiral, 2007; Özdaşlı ve Çelikkol, 2012). Bu bağlamda öğretmenlerin duygusal emek gösterimlerinin psikolojik sözleşmeleri üzerinde etkili olabileceği düşünülebilmektedir. Çünkü çalışanlar psikolojik sözleşmenin oluşum sürecinde örgüte sağlamakla yükümlü olduklarını düşündükleri sorumluluklar ile örgütten maddi ve manevi kazanım beklentileri arasında bağ kurmaktadırlar (Koçak, 2016). Çalışanların duygusal emek gösterimleri sonucunda kurumlarında beklentilerine ve hedeflerine ulaşmalarının, mesleklerine olan bağlılığına, motivasyonuna, performansına ve iş doyumuna olumlu etkileri bulunmaktadır (Beğenirbaş ve Yalçın, 2012; Güngör Delen, 2017). Aksi takdirde duygusal emek gösteriminin öğretmenler üzerinde tükenmişlik, performans düşüklüğü, duyarsızlaşma ve yabancilaşma gibi olumsuz sonuçlara yol açabileceği belirtilmektedir (Isenbarger ve Zembylas, 2006). Okulların hedeflerine ulaşa- 
bilmelerinde anahtar rol oynayan öğretmenlerin psikolojik sözleşmelerine uyma düzeylerinin önemli olduğu ifade edilebilmektedir. Öğretmenlerin psikolojik sözleşmeye yönelik beklentilerinin karşılanmaması yani psikolojik sözleşmeye uyma düzeylerinin düşmesi, onlarda işten ayrılma niyeti, işe devamsızlık ve işe olan bağlılıkta azalma gibi olumsuz sonuçlara yol açabilmektedir (Turnley ve Feldman, 2000). Bu araştırmayla, öğretmenlerin duygusal emek gösterimlerine karşılık kurumlarından beklentilerinin psikolojik sözleşmelerini etkileyebileceği konusunda eğitim yöneticilerinde farkındalık sağlanması ve Milli Eğitim Bakanlığı tarafından eğitim alanında gerçekleştirilmeye çalışılan reformsal düzenlemeler üzerinde etkili olunması umulmaktadır. Aşağıda araştırma değişkenlerine ilişkin kavramsal açıklamalara yer verilmiştir.

\section{Duygusal emek}

Duyguların çalışma hayatında büyük bir etkisi bulunmaktadır. Örgütsel alanda Taylorist düşüncenin hâkim olduğu dönemde çalışanların, duyguları göz ardı edilerek makine gibi görülmüş ve kendilerinden en üst düzeyde verim alma üzerine kurulu bu anlayış, 1980'lere kadar hâkimiyetini sürdürmüştür. Hawthorne çalışmaları ile ortaya konulan bu gerçek, örgütlerde rasyonalizm ile birlikte duyguların da önem kazandığı bir dönemin başlamasına yol açmıştır (Alemdar, 2019). Duygusal emek kavramı ilk olarak "Yönetilen Kalpler: İnsan Duygularının Ticarileşmesi (The Managed Heart: Commercialization of Human Feeling)" adlı kitapta ele alınmıştır. Hochschil (1983) havayolu şirketlerinde çalışan kabin görevlilerinin, yolcular ile etkileşime girdikleri esnada, onların kendilerini daha iyi ve güvende hissetmeleri için sürekli olarak güler yüz göstermelerinin beklenmesinden yola çıarak duygusal emek kavramını ileri sürmüş ve duygusal emeği "bir ücret karşılığında duyguların düzenlenmesi” olarak tanımlanmıştır (Ünler Öz, 2007). Grandey (2000) duygusal emeği "hem duyguların hem de duygu gösterimlerinin örgütsel amaçlara ulaşma adına düzenlenmesi sürecinde harcanan çaba" olarak tanımlamıştır (Akt. Savaş, 2012).

Duygusal emeğin yüz yüze ve bedensel ifadeler olarak sergilenmesinin gözlemlenmesinin yanında, konuşma ses tonu, jest, mimik ve hareketleri kapsayan çabayı da içerdiği belirtilmektedir (Basım \& Begenirbaş, 2012). Kruml ve Geddes (2000), yapılan işin kalitesini yükseltmek amacıyla, çallşanların belirli duyguları hissetmeleri veya en azından belirli duygu göste- 
rimlerini planlamaları gerektiğinde sergiledikleri duygusal davranış örüntülerini, duygusal emek şeklinde değerlendirmiştir (Deliveli, 2018). Diefendorff ve Gosserand $(2003,2005)$ duygusal emeği, çalışanın örgütsel amaçlarını gerçekleştirebilmek adına gösterim kurallarına uygun olarak duygularını düzenlemesi ve çalışma esnasında etkileşim içerisinde olduğu kişilerin (müşteri, çalışma arkadaşları, yöneticiler vb.) duygularını etkileme çabası olarak tanımlamışlardır. Duyusal emek gösteriminde üç noktaya özellikle dikkat çekmiştir. Bunlardan birincisi, duygusal gösterimlerin örgütün isteği ve yönlendirmesi üzerine gerçekleşmesi; ikincisi, duygusal gösterim sürecinde kişisel duygu yönetiminin çok ciddi bir gayret gerektirdiği; üçüncüsü ise, sürecin sonunda duyguların kendilerine değişim değeri yüklenen birer metaya dönüşmesidir (Güngör Delen, 2017).

Hochschild (1983), kişilerin duygu yönetimleri esnasında sergiledikleri gösterimleri yüzeysel rol yapma ve derinden rol yapma biçiminde ifade ettiklerini söylemektedir. Yüzeysel rol yapma, kişinin hissettiği içsel durumu değiştirmeden sadece karşısındaki tarafından gözlenecek olan dışsal tepkisini ayarlamaya çalışmasıdır. Derinlemesine rol yapma davranışında ise kişi, karşındaki ile empati kurmaya çalışarak kendi duygularını muhatabının duygularına uygun hale getirmeye çalışmaktadır. Derinlemesine davranışta yüzeysel davranışa oranla daha fazla duygu paylaşımı söz konusu olduğu için bu davranış türünün yüzeysel davranıştan daha fazla fayda sağladığ1 söylenmektedir (Mavi, 2015; Ünler Öz, 2007). Ashforth ve Humphrey (1993), Hochschild'e ait duygusal emeğin yüzeysel ve derinden rol yapmayı kabul etmekte, bunların yanına bir de çalışanın herhangi bir gayret göstermeden içinden geldiği duyguları hissetme durumu olan samimi davranış ya da doğal duygular boyutunu eklemişlerdir (Ünler Öz, 2007).

Örgütlerde uzun süreli duygusal emek gösteriminin çalışanda oluşturduğu psikolojik uyarılmalar, stres ve tükenmişlik ve örgüte yabancılaşması, işten ayrılma, işe devamsızlık ve geri çekilme davranışlarına sebep olmaktadır. Örgütsel açıdan ise, sürekli çalışan devri, hizmet alanların taleplerini karşılayama ve düşen çalışan performansı gibi durumlar oluşturabilmektedir. Bununla birlikte duygusal emek alanında yapılan çalışmaların büyük bir bölümü, duygusal emek gösteriminin çalş̧anlarda genellikle olumsuz, örgütte ise olumlu sonuçlara yol açtığı tezini desteklemişlerdir (Erken, 2018; Güngör Delen, 2017). 


\section{Psikolojik sözleşme}

Sözleşme, çalışan ve örgütün birbirlerinden karşıllklı beklentilerinden oluşmaktadır. Bu beklentilerin bir kısmı formal ve yazılıdır. Bu tip sözleşmeler "yasal sözleşmeler" olarak adlandırılmaktadır. Yasal sözleşmelerin amacı, çalışan ve örgüt arasındaki yasal zorunlulukları yerine getirmek ve her iki tarafı hakları bağlamında koruma ve denetim altına almaktır. Yasal sözleşmelerin, çalışan ve örgütün beklenti ve sorumluluklarını tam olarak karşılayamaması, psikolojik sözleşmelerin ortaya çıkmasına sebep olmuştur (Mimaroğlu, 2008). Psikolojik sözleşmeleri ise, karşılıklı beklentilerin büyük bir bölümünü oluşturan örtük, informal ve yazılı olmayan vaatler, yükümlülükler ve istekler oluşturmaktadır (Karcığlu ve Türker, 2010; Morrison ve Robinson, 1997). Çalışan ve örgüt arasındaki değişim ilişkisi üzerine kurulu psikolojik sözleşme kavramı, karşılıklı kazanım ve taahhütlerden oluşmaktadır. Çalışan ve örgüt, süreç içerisinde devamlı olarak fayda-maliyet analizi yapmakta ve bu durum da kazanım ve taahhütlerin sık sık güncellenmesine sebep olmaktadır (Özdaşlı ve Çelikkol, 2012).

Psikolojik sözleşme, çalışanların iş sözleşmesine olan inançlarına ve yorumlarına odaklanmaktadır. Yasal sözleşmelerin aksine, psikolojik sözleşme doğası gereği algısal olup çalışan ve örgütün anlama ve yorumlanması farklı olabilmektedir (Robinson, 1996; Rousseau ve Parks, 1993). Çalışanların örgütün kültürü ve iklimi ile ilgili zaman içinde edindikleri algılarda psikolojik sözleşmeyi devamlı olarak şekillendirmektedir (Özdaşlı ve Çelikkol, 2012). Psikolojik sözleşmenin, değişim ilişkisinin taraflarına ait beklentileri açısından; örgütün çalışandan beklentileri işe devamlılık, sadakat, örgüte ait bilgileri korumak, gönüllülük ve kaliteli iş yapmak iken; çalışanın da örgütten beklentileri, bulunduğu işte terfi almak, maaş ve prim, iş eğitimi, kariyer gelişimi, iş güvenliği ve kişisel problemlerin çözülmesi şeklinde olabilmektedir (Knights ve Kennedy, 2015, Akt. Sağır ve Ekici, 2020).

Psikolojik sözleşme işlemsel ve ilişkisel sözleşme olarak iki grupta ele alınabilmektedir. İşlemsel sözleşmeler taraflar arasındaki herhangi bir işlem sonunda sona eren, kısa vadeli ve paraya çevrilebilir yükümlülüklerden oluşmaktadır. İlişkisel sözleşme ise, geniş, açık uçlu ve uzun vadeli yükümlülükler gerektirmekte ve sadece para kazanılabilir unsurlara değil, aynı zamanda sadakat ve destek gibi sosyo-duygusal unsurlara da dayanmaktadır. İlişkisel Psikolojik Sözleşmeler, genellikle uzun vadeli olma eğiliminde 
olup ve çalışan ile örgütün birbirlerine olan karşılıklı bağlılık durumlarına vurgu yapmaktadır. İlişkisel sözleşmeler ekonomik yükümlülüklerin ötesinde içsel değerler, bağlılık ve ortak inançları içermektedir. Bu tip sözleşmeler içerik olarak genellikle daha geniş ve açı uçlu sosyal ve duygusal yükümlülükleri ihtiva etmektedirler (Gautier, 2015; George, 2010; Morrison ve Robinson, 1997; Rousseau, 1998). Psikolojik sözleşmenin oluşumu, örgüt ile çalışanın bir diğeri ile ilgili zihinsel haritalarını oluşturup, bu haritaları zamanla geliştirdikleri bir süreçtir (George, 2010).

Psikolojik sözleşme kavramı örgütsel davranış literatürüne 1980'li yıllarda girmiş olsa da, kavramın temelini oluşturan ve örgütsel bir değer yükleyen çeşitli kuramlar mevcuttur. Bu kuramlar insan davranışlarını anlamamızda önemli bir etkiye sahiptir. Kavramının gelişimine 1şık tutan başlıca kuramlar: karşlıklılık normu, sosyal mübadele kuramı, eşitlik kuramı ve beklenti kuramıdır (Çağlayan, 2016). Karşılıklılık normuna göre, örgüt ya da çalışanın, karşılıklı yükümlülükleri yerine getirme noktasında çalışanın sağlamayı taahhüt ettiği bağlılık ve katkıya, örgütün uygun bir kazanç ile karşılık vermesi temeline dayanmaktadır (Çağlayan, 2016). Sosyal takas kuramı, tarafların birbirinden beklentilerin karşılanması esasına dayalı olarak ilişkileri sürdürdüğü temeline dayanmaktadır Sosyal takasta da karşılıklı kazanç elde etme beklentisi söz konusudur (Cihangiroğlu ve Şahin, 2010). Eşitlik kuramında çalışan, diğer çalışanları gözlemleyerek onlara nasıl davranıldığını, kendisine gösterilen yaklaşım ile diğer çalışanlara sergilenen yaklaşımlar arasında karşılaştırma yaparak sonucunda eşitlik ile ilgili bir yargıya varmasıdır. Bu yargı sonucunda kişi çalışma ortamında bir eşitsizlik algısına kapılırsa, kendisine adil davranılmadığını düşünüp mutsuz olmaktadır (Koçak, 2016). Beklenti kuramı, çalışanın işi için sarf ettiği gayret sonucunda bir ödül ya da kazanım elde etmeyi beklemesidir (Güney, 2017, Koçak, 2016).

Psikolojik sözleşmeler, çalışanların örgütler için başarının anahtarı olan hedeflere ulaşmasına katkıda bulunmak adına, yeteneklerini ve becerilerini geliştirmelerine ve kullanmalarına izin verecek şekilde onları yönlendirmektedir. Örgütte buna karşılık çalışan davranışlarını daha iyi anlamakta onun örgütün stratejik hedeflerine daha etkin bir şekilde yoğunlaşmasını sağlayabilmektedir (Michael, 2012). Psikolojik sözleşme ile çalışan ve örgüt arasındaki güvensizlik ve belirsizlik minimize edilebilmekte ve yazılı sözleşmelerin eksiklikleri kapatabilmektedir (Cihangiroğlu ve Şahin, 2010). 
Yukarıdaki alan yazın açıklamalarından öğretmenlerin duygu gösterimleri ile psikolojik sözleşmeleri arasında ilişkiler bunabileceği düşünülebilmektedir. Öğretmenlerin okullarında yerine getirdikleri görev ve sorumluluklarına, okulunun gelişimine yönelik gösterdiği gayret ve ekstra çalışmalarına ilişkin harcamak durumunda kaldıkları zihinsel, bedensel ve duygusal çabaları karşılığında, okulundan ve okul yönetiminden karşılanmasını istediği bazı beklentiler içine girebileceği belirtilebilmektedir. Alan yazın incelendiğinde, öğretmenlerin duygusal emek gösterimleri ile iş doyumu, yaşam doyum düzeyi, tükenmişlik, örgütsel bağlılık, örgütsel adalet, örgütsel yabancılaşma ve örgütsel vatandaşlık gibi farklı değişkenlerin ilişkisine yönelik yapılan araştırmalara (Akbaş ve Bostancı, 2019; Alev, 2018; Alemdar, 2019; Basım, Begenirbaş ve Yalçın, 2013; Cingöz ,2018; Göç ,2017; Çekiç ve Göç, 2016; Erken, 2018; Ertürk, Kara ve Güneş, 2016; Hoşgörür ve Yorulmaz, 2015; Moran, 2018; Y1lmaz, Altınkurt, Güner ve Şen 2015; Yılmaz Daban, 2018) rastlanmaktadır. Yine araştırmanın diğer değişkeni psikolojik sözleşme ile örgütsel bağlılık, liderlik davranışları, sosyal sermaye, örgütsel güven, okul DNA profilleri ve iş doyumu gibi farklı değişkenlerin (Çavuş, 2018; Çay, 2019; Doğan, 2017; Dönmez, 2015; Koçak, 2016; Y1lmaz ve Altınkurt, 2012) araştırmalara konu olduğu görülmektedir. Fakat iki değişkenin ilişkisi üzerine yapılan araştırmalar yok denecek kadar azdır. Xuan ve Park (2012), tarafından Çin devlet üniversitelerinde yapılan araştırmada psikolojik sözleşmenin duygusal emek üzerinde önemli bir etkisi olduğu sonucuna ulaşılmıştır (Akt. Sağır ve Ekici, 2020). Sağır ve Ekici (2020) sanayi işletmeleri üzerine bir çalışma yapmış ve çalışmalarında psikolojik sözleşme ile duygusal emek gösterimi arasında pozitif yönlü anlamlı bir ilişki olduğunu belirlemişlerdir. Öğretmenlere yönelik ise, ilgili değişkenlerin birbiri ile ilişkisi üzerine herhangi bir araştırmaya rastlanmamıştır. Bu araştırmada, öğretmenlerin duygusal emek gösterimleri ile psikolojik sözleşmeye uyma düzeyleri arasındaki ilişkinin araştırılması amaçlanmıştır. Araştırmanın amacı doğrultusunda araştırmada aşağıdaki sorulara cevap aranmıştır.

1. Öğretmenlerin genel duygusal emek gösterimleri ne düzeydedir?

2. Öğretmenlerin duygusal emek gösterimleri görev yapılan okul düzeyine, cinsiyetlerine, mesleki kıdemlerine, mezuniyet durumlarına, görev yaptığı okulundaki öğretmen sayısına ve aynı okulda görev sürelerine göre farklılaşmakta mıdır?

3. Öğretmenlerin psikolojik sözleşmeye uyma düzeyleri nedir? 
4. Öğretmenlerin psikolojik sözleşmeye uyma düzeyleri, görev yapılan okul düzeyine, cinsiyetlerine, mesleki kıdemlerine, mezuniyet durumlarına, görev yaptığı okulundaki öğretmen sayısına ve aynı okulda görev sürelerine göre farklılaşmakta mıdır?

5. Öğretmenlerin duygusal emek gösterimleri ile psikolojik sözleşmeye uyma düzeyleri arasında anlamlı bir ilişki var mıdır?

6. Öğretmenlerin duygusal emek gösterimleri, psikolojik sözleşmeye uyma düzeylerini yordamakta mıdır?

\section{Yöntem}

Araştırmanın bu bölümünde, araştırma modeli, araştırma evreni ve örneklemi, veri toplama ve veri analizine yönelik açıklamalar yer almaktadır.

\section{Araştırma modeli}

Bu araştırma, öğretmenlerin duygusal emek gösterimleri ile çalıştıkları okula karşı oluşturdukları psikolojik sözleşmeye uyma düzeyleri arasındaki ilişkiyi belirlemek amacıyla yapıldığı için, ilişkisel tarama modeli kullanılarak gerçekleştirilmektedir. İlişkisel tarama, iki veya daha çok değişkenin arasında birlikte bir değişmenin varolma durumuna veya yokluğunu ve bir değişim varsa, değişimi derece olarak belirlemeyi amaçlayan bir modeldir (Karasar, 2005).

\section{Evren ve örneklem}

Araştırma evreni, 2019-2020 eğitim öğretim yıl içerisinde Kütahya'nın ilçelerinden Gediz, Simav, Şaphane ile Çavdarhisar ilçelerinde yer alan resmi ilkokul, ortaokul ve liselerde görevini sürdüren öğretmenlerdir. Araştırmanın evreni 1502 öğretmenden oluşturmaktadır. Araştırma örnekleminin belirlenmesi için kuramsal örneklem büyüklüğü çizelgesinden faydalanılmıştır. Çizelgede 5000 kişilik evrende \%95'lik güven düzeyi, $\alpha=.05$ anlaml1lık ve \%5'lik hoşgörü düzeyi için örneklem büyüklüğünün minimum 356 kişi olması gerektiği tespit edilmişti (Balc1, 2011). Bu bakımdan, araştırmanın örneklemini kolay ulaşılabilir örnekleme tekniği ile seçilen ve bahsi geçen ilçelerde görev yapan 405 öğretmen oluşturmaktadır. Ölçekler araştırmacı tarafından ulaşım maliyet zaman vb. özellikler dikkate alınarak kolay ulaşılabilen okullardaki öğretmenlere uygulanmıştır. Verilerin girilmesi 
sırasında toplanan ölçekler incelenmiş ve tüm ölçekler geçerli olarak kabul edildiğinden eleme yoluna gidilmemiştir. Araştırmanın örneklemini oluşturan öğretmenlerin demografik veriler cinsiyet, görev yapılan okul düzeyi, kıdem, mezuniyet durumu, okuldaki öğretmen sayısı ve aynı okulda yaklaşık çalışma süresi demografik verileri Tablo 1'de görülmektedir.

Tablo 1.Araştımanın örneklemine ilişkin demografik bilgiler

\begin{tabular}{|c|c|c|c|}
\hline \multicolumn{2}{|l|}{ Demografik Özellikler } & \multirow{2}{*}{$\begin{array}{l}\text { Sayı } \\
222\end{array}$} & \multirow{2}{*}{$\begin{array}{l}\text { Yüzde } \\
54.8\end{array}$} \\
\hline Cinsiyet & Kadın & & \\
\hline & Erkek & 183 & 45.2 \\
\hline & $1-10 Y_{1}$ & 158 & 39.0 \\
\hline \multirow[t]{2}{*}{ Kıdem } & $11-20 Y_{11}$ & 131 & 32.3 \\
\hline & 21 Yll ve Üzeri & 116 & 28.6 \\
\hline \multirow[t]{2}{*}{ Okuldaki Öğretmen Sayısı } & 1-20 Kişi & 158 & 39.0 \\
\hline & 21 ve Üzeri Kişi & 247 & 61.0 \\
\hline \multirow[t]{2}{*}{ Mezuniyet Durumu } & Lisans & 350 & 86.4 \\
\hline & Lisansüstü & 55 & 13.6 \\
\hline \multirow[t]{3}{*}{ Çalışılan Okul Düzeyi } & İlkokul & 112 & 27.7 \\
\hline & Ortaokul & 120 & 29.6 \\
\hline & Lise & 173 & 42.7 \\
\hline \multirow[t]{3}{*}{ Aynı Okulda Çalışma Süresi } & $1-3 Y_{11}$ & 178 & 44.0 \\
\hline & 4-6 Yil & 120 & 29.6 \\
\hline & 7 Yil ve Üzeri & 107 & 26.4 \\
\hline TOPLAM & & 405 & 100 \\
\hline
\end{tabular}

Tablo 1.'e göre araştırma örneklemini oluşturan öğretmenlerin cinsiyet durumları incelendiğinde, kadın öğretmen sayısının 222 (\%54.8), erkek öğretmen sayısının ise 183 (\%45.2) olduğu görülmektedir. Öğretmenlerin görev yaptıkları okulların düzeyine göre 112 (\%27.7) ilkokul, 120 (\%29.6) ortaokul ve 173 (\%42.7) lise öğretmeninin varlığı tespit edilmiştir. Öğretmenlerin mesleki kıdemi 1-10 yıl olan öğretmen sayısı 158 (\%39.0), kıdemi 11-20 y1l olan öğretmen 131 (\%32.3) ve 21 y1l ve daha fazla kıdeme sahip öğretmen sayısı ise 116'dır (\%28.6). Mezuniyet durumu açısından lisans eğitimine sahip öğretmen sayısı 350 (\%86.4), lisansüstü eğitime sahip öğretmen sayısı ise 55'tir (\%13.6). Görev yaptıkları okullardaki öğretmen sayısına göre, okulunda 1-20 arası öğretmen bulunan öğretmenlerin sayısı 158 (\%39.0), okulunda 21 ve üzeri öğretmen bulunan öğretmenlerin sayısı ise 247'dir (\%61.0). Araştırmaya katılan öğretmenlerin aynı okulda çalışma süresine göre dağılımı incelendiğinde, aynı okulda 1-3 yıl çalışma süresine sahip öğretmenlerin sayısının 178 (\%44.0), 4-6 yıl çalışma süresine sahip öğretmenlerin sayı- 
sinın 120 (\%29.6) ve 7 yıl ve üzeri çalışma süresine sahip öğretmenlerin sayısını ise 107 (\%26.4) olduğu belirlenmiştir.

\section{Veri toplama araçlar}

Araştırmada, öğretmenlerin duygusal emek gösterimlerini belirlemek için "Duygusal Emek Ölçeği” ile psikolojik sözleşmeye uyma düzeylerini belirlemek amaciyla ise, "Psikolojik Sözleşmeye Uyma Düzeyi Ölçeği" uygulanmıştır.

Duygusal emek ölçeği: Duygusal emek ölçeği Diefendorff ve arkadaşlarınca (2005) geliştirilmiş, Basım ve Begenirbaş (2012) tarafından Türkçe' ye uyarlaması yapılmıştır. Ölçek, yüzeysel rol yapma, derinden rol yapma ve doğal duygular boyutlarından oluşmaktadır ve 13 maddedir. Ölçek 1=Hiçbir Zaman'dan 5=Her Zaman'a doğru beşli Likert derecelendirme şeklindedir. Basım ve Begenirbaş (2012) tarafından ölçeğin Cronbach Alpha güvenilirlik katsayısı, yüzeysel rol yapma boyutunda $\alpha=0.83$, derinden rol yapma boyutunda $\alpha=0.87$ ve doğal duygular boyutunda ise $\alpha=0.80$ olarak hesaplanmıştrr. Bu araştırmada ölçeğin Cronbach Alpha Güvenilirlik katsayılarına bakıldığında ise yüzeysel rol yapma boyutunda $\alpha=0.87$, derinden rol yapma boyutunda $\alpha=0.91$ ve doğal duygular boyutunda ise $\alpha=0.87$ olduğu tespit edilmiştir. Bu araştırma için ölçeğin Cronbach Alpha Güvenirlik katsayılarının istenilen .70 değerinin üstünde olduğu tespit edilmiştir (Büyüköztürk, 2012; Seçer, 2013). Bunun yanı sıra, duygusal emek ölçeğinin güvenirliğinin, Basım ve Begenirbaş (2012) tarafından geliştirilen ölçeğin güvenirlik katsayıları ile yakın değerlere sahip olduğu görülmektedir. Bu sonuçlardan hareketle duygusal emek ölçeğinin güvenilir ve kabul edilebilir düzeyde olduğu görülmektedir. Ayrıca araştırmada ölçeğin doğrulayıcı faktör analizi yapılmıştır. Analiz sonucunda, uyum iyiliği değerlerinin $\chi 2=123.04 ; \mathrm{df}=62$; $\chi 2 / \mathrm{df}=1.98$; RMSEA=0.070; $\mathrm{GFI}=0.91 ; \mathrm{CFI}=0.96 ; \mathrm{NFI}=0.92$ olarak bulunmuştur.

Psikolojik sözleşmeye uyma düzeyi ölçeği: Öğretmenlerin psikolojik sözleşmeye uymalarına yönelik alg1 düzeyleri, Koçak (2016) tarafından geliştirilen "Psikolojik Sözleşmeye Uyma Düzeyi Ölçeği" ile ölçülmüştür. Ölçek, kurumsal gelişme yönelik çaba, ekstra performans ve sadakat olmak üzere üç alt boyutu içeren 26 maddeden oluşmaktadır. Öğretmenler ölçeği beşli Likert 
şeklinde değerlendirmişlerdir (1=Hiç Katılmıyorum, 5=Tamamen Katılıyorum). Ölçeğin özgün halindeki Cronbach Alpha Güvenilirlik Katsayıları; kurumsal gelişime yönelik çaba boyutunda $\alpha=0.89$, ekstra performans boyutunda $\alpha=0.84$ ve doğal duygular boyutunda $\alpha=0.80^{\prime}$ dir (Koçak, 2016). Bu araştırmada ölçeğin Cronbach Alpha Güvenilirlik Katsayıları ise; kurumsal gelişime yönelik çaba boyutunda için $\alpha=0.95$, ekstra performans boyutunda $\alpha=0.80$ ve sadakat boyutunda ise $\alpha=0.83$ olarak tespit edilmiştir. Bu ölçeğin toplam güvenilirlik katsayısı ise .94 olarak bulunuştur. Yine bu ölçeğe ait Cronbach Alpha güvenirlik katsayılarının istenilen 70 değerinin üstünde olduğu tespit edilmiştir(Büyüköztürk, 2012; Seçer, 2013). Bunun yanında bu ölçeğin de araştırma için doğrulayıcı faktör analizi yapılmıştır. Analiz sonucunda, uyum iyiliği değerleri, $\chi 2=470.29 ; \mathrm{df}=296 ; \chi 2 / \mathrm{df}=1.58 ; \mathrm{RMSEA}=0.077 ; \mathrm{GFI}=0.83 ; \mathrm{CFI}=0.95$; $\mathrm{NFI}=0.85$ olarak tespit edilmiştir.

\section{Verilerin analizi}

Araştırmada elde edilen verilere uygulanacak analizlerin belirlenebilmesi için, verilere çarpıklık ve basıklık katsayıları incelenmiştir. "Duygusal Emek Ölçeği" ve "Psikolojik Sözleşmeye Uyma Düzeyi Ölçeği" ile toplanan veriler üzerinde hesaplanan araştırma değişkenlerinin çarpıklık-basıklık katsayılarının istenilen değerler arasında olmasından dolayı verilerin normal dağıldığı anlaşılmıştır (Kalaycı, 2009). Tablo 2'de verilerin çarpıklık basıklık testi sonuçları sunulmuştur.

Tablo 2. Araştırmanın verilerin normal dağılıp dağılmama durumlarına ilişkin sonuçlar

\begin{tabular}{lll}
\hline Boyutlar & Çarpıklık & Basıklık \\
\hline Yüzeysel Rol Yapma & .501 & -.571 \\
\hline Derinden Rol Yapma & -.646 & -.552 \\
\hline Doğal Duygular & -1.285 & 2.227 \\
\hline Kurumsal Gelişime Yönelik Çaba & -1.582 & 2.735 \\
\hline Ekstra Performans & -.526 & -.203 \\
\hline Sadakat & -.646 & .037 \\
\hline Psikoloji Sözleşme Toplam & -1.020 & .932 \\
\hline
\end{tabular}

Tablo 2'de yer alan elde edilen hesaplamalar doğrultusunda, Duygusal Emek ve Psikolojik Sözleşmenin tüm boyutları için hesaplanan çarpıklık ve basıklık katsayılarının istenen değerler arasında olduğu görülmektedir. Bunun için öğretmenlerin duygusal emek gösterimleri ile psikolojik sözleşmeye uyma düzeylerinin cinsiyetleri, mezuniyet durumları ve görev yaptık- 
ları okulun öğretmen sayısına ilişkin anlamlı olarak farklılaşıp farklılaşmadığını belirlemek için“Bağımsız Örneklemler t-Testi” kullanılmıştır. Öğretmenlerin duygusal emek gösterimleri ile psikolojik sözleşmeye uyma düzeylerinin görev yapılan okul düzeyi, kıdem yılı ve aynı okulda görev yapma süresine göre anlamlı bir şekilde farklılık gösterip göstermediğini ortaya koymak amacıyla ise "Tek Yönlü Varyans Analizi (ANOVA)" kullanılmıştır. Gruplar arasında oluşan farkların hangi grup veya gruplardan oluştuğunu belirlemek için TUKEY HSD testi uygulanmış ve anlamlılık düzeyi .05 olarak kabul edilmiştir. Daha sonra öğretmenlerin duygusal emek gösterimleri ile psikolojik sözleşmeye uyma düzeylerinin aralarında bir ilişki olup olmadığına bakmak için ise Pearson Momentler Çarpımı Korelasyonu kullanılmıştır. Ayrıca araştırma değişkenleri arasında çoklu bağlantılılık problemine yönelik VIF ve tolerans değeri hesaplanmıştır. VIF değerlerinin 1.122 ile 1.274 aralı̆̆ında olması, tolerans değerlerinin ise .785 ile .892 aral1ğında olmasıyla, tolerans değerlerinin .02 'den büyük, VIF değerlerinin ise 10 'dan küçük olduğu tespit edilmiş ve çoklu bağlantılılık problemi bulunmadığı anlaşılmıştır (Seçer, 2013). Öğretmenlerin duygusal emek gösterimlerinin psikolojik sözleşmeye uyma düzeylerini yordayıp yordamadığını belirlemek için çoklu regresyon analizi yapılmıştır.

\section{Bulgular}

$\mathrm{Bu}$ bölümde, araştırmanın problemi ve alt problemlerine yönelik analizler sonucunda elde edilen bulgulara yer verilmiştir. Öğretmenlerin duygusal emek gösterimlerine yönelik algı düzeylerine ait betimsel istatistiklere Tablo $3^{\prime}$ te yer verilmiştir.

Tablo 3. Öğretmenlerin duygusal emek gösterimlerine ilişkin algılarına yönelik betimsel istatistikler

\begin{tabular}{llll}
\hline Duygu sal Emek & $\bar{X}$ & Ss & Düzey \\
\hline Yüzeysel Rol Yapma & 2.30 & .942 & Düşük \\
\hline Derinden Rol Yapma & 3.45 & 1.177 & Yüksek \\
\hline Doğal Duygular & 4.22 & .774 & Çok Yüksek \\
\hline
\end{tabular}

Tablo 3 incelendiğinde, öğretmenlerin duygusal emek gösterimlerinin yüzeysel rol yapma $(\bar{X}=2.30)$ boyutunda düşük, derinden rol yapma $(\bar{X}=$ 3.45) boyutunda yüksek, doğal duygular ( $\bar{X}=4.22$ )boyutunda ise çok yük- 
sek olduğu anlaşılmaktadır. Tablo 4' te ise, çalışılan okul düzeyi değişkenine göre öğretmenlerin duygusal emek gösterimlerine yönelik algılarına ilişkin bulgular yer almaktadır.

Tablo 4. Çalışılan okul düzeyine göre öğretmenlerin duygusal emek gösterimlerine yönelik algılarnna ilişkin ANOVA Testi sonuçları

\begin{tabular}{lllllllllll}
\hline $\begin{array}{l}\text { Duygusal } \\
\text { Emek }\end{array}$ & $\begin{array}{l}\text { Okul } \\
\text { Düzey }\end{array}$ & $\mathbf{N}$ & $\bar{X}$ & Ss & Var. K & KT & Sd & KO & F & p \\
\hline Yüzeysel & İlkokul(1) & 112 & 2.39 & .981 & G.Arası & 1.410 & 2 & .705 & .794 & .453 \\
Rol Yapma & Ortaokul(2) & 120 & 2.28 & 1.01 & G.İçi & 356.890 & 402 & .888 & & \\
& Lise(3) & 173 & 2.26 & .869 & Top. & 358.300 & 404 & & & \\
\hline Derinden & İlkokul(1) & 112 & 3.54 & 1.257 & G.Arası & 5.237 & 2 & 2.619 & 1.898 & .151 \\
Rol Yapma & Ortaokul(2) & 120 & 3.56 & 1.153 & G.İçi & 554.707 & 402 & 1.380 & & \\
& Lise(3) & 173 & 3.32 & 1.136 & Top. & 559.944 & 404 & & & \\
\hline Doğal & İlkokul(1) & 112 & 4.24 & .785 & G.Arası & 3.506 & 2 & 1.753 & 2.951 & .053 Yok \\
Duygular & Ortaokul(2) & 120 & 4.35 & .677 & G.İçi & 238.747 & 402 & .594 & & \\
& Lise(3) & 173 & 4.13 & .821 & Top. & 242.252 & 404 & & & \\
\hline
\end{tabular}

Tablo 4'e göre, öğretmenlerin duygusal emek gösterimlerinin yüzeysel rol yapma $\left[\mathrm{F}_{(2-402)}=.794 ; \mathrm{p}>0.05\right]$, derinden rol yapma $\left[\mathrm{F}_{(2-402)}=1.898 ; \mathrm{p}>0.05\right]$ ve doğal duygular $\left[\mathrm{F}_{(2-402)}=2.951 ; \mathrm{p}>0.05\right]$ boyutlarında görev yapılan okul düzeyi değişkenine göre istatistiksel olarak anlamlı bir farklılık göstermediği görülmektedir. Öğretmenlerin duygusal emek gösterimlerine yönelik algıları, araştırmada yer alan diğer demografik değişkenlere göre analiz sonuçları aşağıdaki şekildedir.

Cinsiyet değişeni bakımından, öğretmenlerin duygusal emek gösterimlerinin, duygusal emeğin yüzeysel rol yapma $\left[t_{(405)}=-2.410, p<0.05\right]$ ve derinden rol yapma [ $\left.\mathrm{t}_{(405)}=-3.127, \mathrm{p}<0.05\right]$ boyutlarında anlamlı bir şekilde farklılaştığ 1 görülmüştür. Erkek öğretmenler duygusal emeğin yüzeysel rol yapma ve derinden rol yapma boyutlarında daha yüksek düzeyde duygusal emek gösteriminde bulunmaktadırlar. Doğal duygular $\left[\mathrm{t}_{(405)}=1.691\right.$, p $>0.05$ ]boyutunda ise, öğretmenlerin cinsiyetlerine göre duygu gösterimleri arasında anlamlı bir fark tespit edilmemiştir.

Kıdem yılı değişkeni bakımından, öğretmenlerin duygusal emek gösterimlerine ait algılarının, duygusal emeğin yüzeysel rol yapma $\left[\mathrm{F}_{(2-402)}=1.305\right.$; $\mathrm{p}>0.05]$, derinden rol yapma $[\mathrm{F}(2-402)=1.796 ; \mathrm{p}>0.05]$ ve doğal duygular $\left[\mathrm{F}_{(2-402)}\right.$ $=.067 ; \mathrm{p}>0.05]$ boyutlarında Farklılaşmaktadır. Kıdemi 1-10 yıl, 11-20 yıl ve 21 yıl ve üzeri olan öğretmenlerin duygusal emek gösterimlerine yönelik algıları benzerdir 
Mezuniyet durumu değişkeni bakımından, öğretmenlerin duygusal emek gösterimlerine ait algılarında, duygusal emeğin yüzeysel rol yapma [ $\mathrm{t}(405)=$ $.359, \mathrm{p}>0.05]$, derinden rol yapma [ $\left.\mathrm{t}_{(405)}=1.754, \mathrm{p}>0.05\right]$ ve doğal duygular $[\mathrm{t}(405)=1.523, \mathrm{p}>0.05]$ boyutlarında öğretmenlerin lisans ya da lisansüstü eğitim durumlarına sahip olmaları açısından anlamlı bir farklılaşma tespit edilememiştir.

Okuldaki öğretmen sayısı değişkeni bakımından, okulunda 1-20 öğretmen bulunanlar ile okulunda 21 ve üzeri öğretmen bulunan, öğretmenlerin duygusal emek gösterimlerine ait algılarının, duygusal emeğin yüzeysel rol yapma $[\mathrm{t}(405)=-.133, \mathrm{p}>0.05]$, derinden rol yapma [ $\left.\mathrm{t}_{(405)}=1.544, \mathrm{p}>0.05\right]$ ve doğal duygular [t(405) $=-.670, \mathrm{p}>0.05]$ boyutlarında anlamlı olarak farklılaşmadığ 1 görülmüştür.

Aynı okulda çalışma süresi değişkeni bakımından, mevcut okulunda 1-3 yıl, 46 yıl ve 7 yıl ve üzeri çalışma süresi bulunan öğretmenlerin duygusal emek gösterimlerine ait algilarının, duygusal emeğin yüzeysel rol yapma $\left[\mathrm{F}_{(2-402)}=\right.$ .555; $\mathrm{p}>0.05]$, derinden rol yapma $\left[\mathrm{F}_{(2-402)}=1.839 ; \mathrm{p}>0.05\right]$ ve doğal duygular $\left[\mathrm{F}_{(2-402)}=.840 ; \mathrm{p}>0.05\right]$ boyutlarında anlamlı olarak farklılaşmadığı görülmüştür. Öğretmenlerin psikolojik sözleşmeye uymalarına yönelik algı düzeylerine ait betimsel istatistiklere Tablo $3^{\prime}$ te yer verilmiştir.

Tablo 5. Öğretmenlerin psikolojik sözleşmeye uyma düzeyine ilişkin algılarna yönelik betimsel istatistikler

\begin{tabular}{lcll}
\hline Psikolojik sözleşme & $\bar{X}$ & Ss & Düzey \\
\hline Kurumsal Gelişime Yönelik Çaba & 4.27 & .815 & Çok Yüksek \\
\hline Ekstra Performans & 3.90 & .744 & Yüksek \\
\hline Sadakat & 3.76 & .893 & Yüksek \\
\hline Psikolojik Sözleşme & 4.02 & .722 & Yüksek
\end{tabular}

Tablo 5 incelendiğinde, öğretmenlerin psikolojik sözleşmeye uyma düzeyleri, kurumsal gelişime yönelik çaba $(\bar{X}=4.27)$ boyutunda çok yüksek, ekstra performans $(\bar{X}=3.90)$ ve sadakat $(\bar{X}=3.76)$ boyutlarında ise yüksektir. Öğretmenlerin toplamda psikolojik sözleşmeye uyma düzeyleri ( $\bar{X}$ $=4.02$ ) yine yüksek düzeydedir. Tablo 6 da ise, çalışılan okul düzeyi değişkenine göre öğretmenlerin psikolojik sözleşmeye uyma düzeylerine yönelik algılarına ilişkin bulgular görülmektedir. 
Tablo 6. Çalışılan okul düzeyine değişkenine göre öğretmenlerin psikolojik sözleşmeye uyma durumlarna yönelik ANOVA Testi sonuçlar

\begin{tabular}{|c|c|c|c|c|c|c|c|c|c|c|c|}
\hline $\begin{array}{l}\text { Psikolojik } \\
\text { Sözleşme }\end{array}$ & $\begin{array}{l}\text { Okul } \\
\text { Düzeyi }\end{array}$ & $\mathbf{N}$ & $\bar{X}$ & Ss & Var. K & KT & Sd & $\mathrm{KO}$ & $\mathbf{F}$ & p Fark & \\
\hline Kurumsal & İlkokul (1) & 112 & 4.44 & .069 & G.Arası & 6.718 & 2 & 3.359 & 5.164 & $.006 \quad 1-3$ & $1-3$ \\
\hline Gelişime & Ortaokul(2) & 120 & 4.32 & .070 & G.İçi & 261.510 & 402 & .651 & & & \\
\hline Yön. Çaba & Lise (3) & 173 & 4.13 & .067 & Top. & 268.228 & 404 & & & & \\
\hline Ekstra & İlkokul (1) & 112 & 3.98 & .068 & G.Arası & 1.233 & 2 & .617 & 1.113 & .329 Yok & Yok \\
\hline \multirow[t]{2}{*}{ Performans } & Ortaokul(2) & 120 & 3.90 & .073 & G.İçi & 222.692 & 402 & .554 & & & \\
\hline & Lise (3) & 173 & 3.85 & .055 & Top. & 223.926 & 404 & & & & \\
\hline \multirow[t]{3}{*}{ Sadakat } & İlkokul (1) & 112 & 3.97 & .076 & G.Arası & 6.849 & 2 & 3.424 & 4.364 & .013 & $1-2$ \\
\hline & Ortaokul(2) & 120 & 3.68 & .084 & G.İçi & 315.435 & 402 & .785 & & & $1-3$ \\
\hline & Lise (3) & 173 & 3.68 & .069 & Top. & 322.284 & 404 & & & & \\
\hline
\end{tabular}

Tablo 6 incelendiğinde, öğretmenlerin psikolojik sözleşmeye uymalar1nin kurumsal gelişime yönelik çaba $\left[\mathrm{F}_{(2-402)}=5.164 ; \mathrm{p}<0.05\right]$, ekstra performans $\left[\mathrm{F}_{(2-402)}=1.113 ; \mathrm{p}>0.05\right]$ ve sadakat $\left[\mathrm{F}_{(2-402)}=4.364 ; \mathrm{p}>0.05\right]$ boyutlarında çalışlan okul düzeyi değişkenine göre, kurumsal gelişime yönelik çaba alt boyutunda ilkokul ve lise öğretmenlerine ait puan ortalamaları arasında, sadakat alt boyutunda ise, ilkokul ve ortaokul öğretmenleri ile ilkokul ve lise öğretmenlerinin puan ortalamaları arasında anlamlı farklılıklar tespit edilmiştir. Ekstra performans boyutunda, çalışılan okul düzeyine göre ilkokul, ortaokul ve lise öğretmenleri arasında ortalama görüş puanları açısından anlamlı bir fark yoktur. Analiz sonucundaki bulgulara göre, ilkokulda görev yapan öğretmenlerin okullarının kurumsal gelişmeye yönelik çaba ve ekstra performans boyutlarında ortaokul ve lise öğretmenlerine göre psikolojik sözleşme düzeylerinin daha yüksek olduğu görülmektedir. Öğretmenlerin psikolojik sözleşmeye uymalarına yönelik algıları, araştırmada yer alan diğer demografik değişkenlere göre analiz sonuçları aşağıdaki şekildedir.

Cinsiyet değiş̧eni bakımından, öğretmenlerin psikolojik sözleşmeye uymalarına ait algılarının, psikolojik sözleşmenin kurumsal gelişime yönelik çaba $[\mathrm{t}(405)=-.884, \mathrm{p}>0.05]$ ve ekstra performans $[\mathrm{t}(405)=-.360, \mathrm{p}>0.05]$ boyutlarmda anlamlı bir şekilde farklılaşmadığı görülmüştür. Sadakat $[\mathrm{t}(405)=-2.138$, $\mathrm{p}<0.05]$ boyutunda ise, öğretmenlerin cinsiyetlerine göre psikolojik sözleşmeye uyma düzeyleri farklılık göstermektedir. Erkek öğretmenlerin sadakat boyutu daha yüksektir. Bu bağlamda, erkek öğretmenlerin kadın öğretmenlere oranla okullarına karşı daha fazla sadakat duydukları söylenebilir. Psikolojik sözleşmenin geneline [ $t(405)=-1.158, p>0.05]$ yönelik kadın ve erkek öğretmen algıları arasında da anlamlı bir farklılık olmadığı anlaşılmıştır. 
Kıdem yılı değişkeni bakımından, öğretmenlerin psikolojik sözleşmeye uymalarına ait algılarının, psikolojik sözleşmenin kurumsal gelişime yönelik çaba $\left[\mathrm{F}_{(2-402)}=1.354 ; \mathrm{p}>0.05\right]$ boyutunda kıdemi $1-10$ y1l, 11-20 y1l ve 21 yıl ve üzeri olan öğretmenler arasında anlamlı olarak farklılaşmadığı görülmüştür. Ekstra performans $\left[\mathrm{F}_{(2-402)}=3.490 ; \mathrm{p}<0.05\right]$ boyutunda, kıdemi 11-20 y1l olan öğretmenler ile 1-10 yıl olan öğretmenler arasında; sadakat $\left[\mathrm{F}_{(2-402)}=\right.$ 6.551; $\mathrm{p}<0.05$ ] boyutunda ise, kıdemi 21 yıl ve üzeri olan öğretmenler ile kıdemi 1-10 yıl olan öğretmenler arasında, öğretmenlerin psikolojik sözleşmeye uymalarına ait algılarında farklılaşmalar tespit edilmiştir. Psikolojik sözleşmenin toplaminda [ $\left.\mathrm{F}_{(2-402)}=3.460 ; \mathrm{p}>0.05\right], 21$ y1l ve üzeri kıdeme sahip olan öğretmenler ile 1-10 yıl olan kıdeme sahip öğretmenler arasında ve kıdemi 11-20 yıl öğretmenler ile 1-10 yıl olan öğretmenler arasında, öğretmen algılarının anlamlı olarak farklılaştığı görülmüştür. Buna göre, öğretmenlerin kıdem yılı arttıkça psikolojik sözleşmeye uymaya yönelik algıları da doğru orantılı olarak artmaktadır.

Mezuniyet durumu değişkeni bakımından, öğretmenlerin psikolojik sözleşmeye uymalarına ait algılarında, psikolojik sözleşmenin kurumsal gelişime yönelik çaba [ $\left.\mathrm{t}_{(405)}=.604, \mathrm{p}>0.05\right]$, ekstra performans [ $\left.\mathrm{t}_{(405)}=.406, \mathrm{p}>0.05\right]$ ile sadakat $[\mathrm{t}(405)=1.335, \mathrm{p}>0.05]$ boyutlarında ve psikolojik sözleşmeye uyma davranışının toplamında [t(405) $=.814, \mathrm{p}>0.05]$, öğretmenlerin lisans ya da lisansüstü eğitim durumlarına sahip olmaları açısından anlamlı bir farklılaşma tespit edilememiştir.

Okuldaki ögrretmen sayısı değişkeni bakımından, okulunda 1-20 öğretmen bulunanlar ile okulunda 21 ve üzeri öğretmen bulunan öğretmenlerin psikolojik sözleşmeye uymalarına ait algılarının, psikolojik sözleşmenin kurumsal gelişime yönelik çaba [ $\left.\mathrm{t}_{(405)}=1.236, \mathrm{p}>0.05\right]$, ekstra performans $\left[\mathrm{t}_{(405)}=1.758\right.$,

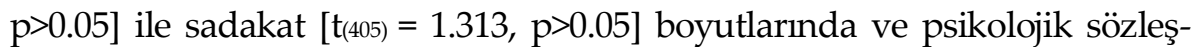
meye uyma davranışının toplamında $[\mathrm{t}(405)=1.592, \mathrm{p}>0.05]$ anlamlı olarak farklılaşmadığı görülmüştür.

Aynı okulda çalışma süresi değişkeni bakımından, mevcut okulunda 1-3 yıl, 46 yıl ve 7 yıl ve üzeri çalışma süresi bulunan öğretmenlerin psikolojik sözleşmeye uymalarına ait algılarının, psikolojik sözleşmenin kurumsal gelişime yönelik çaba $\left[\mathrm{t}_{(405)}=.406 ; \mathrm{p}>0.05\right]$, ekstra performans [ $\left.\mathrm{t}_{(405)}=.590 ; \mathrm{p}>0.05\right]$ ile sadakat $\left[\mathrm{t}_{(405)}=2.018 ; \mathrm{p}>0.05\right]$ boyutlarında ve psikolojik sözleşmeye uyma davranışının toplamında [t(405) $=.880, \mathrm{p}>0.05]$, anlamlı olarak farklılaşmadığı görülmüştür. Tablo 7' de duygusal emek gösterimlerine yönelik öğretmenle- 
rin algıları ile psikolojik sözleşmeye uymalarına yönelik ilişkilerin tespit edilmesine yönelik korelasyon analizine ilişkin sonuçları yer almaktadır.

Tablo 7. Öğretmenlerin duygusal emek gösterimlerine yönelik algılarn ile psikolojik sözleşmeye uyma dïzeyleri arasındaki ilişkiyi gösteren Korelasyon Analizi sonuçları

\begin{tabular}{lllll}
\hline Psikolojik Sözleşme & $\begin{array}{l}\text { Kurumsal Gelişime } \\
\text { Yönelik Çaba }\end{array}$ & $\begin{array}{l}\text { Ekstra } \\
\text { Performans }\end{array}$ & Sadakat & $\begin{array}{l}\text { Psikolojik } \\
\text { Sözleşme }\end{array}$ \\
$\begin{array}{l}\text { Duygusal Emek } \\
\text { Gösterimi }\end{array}$ & & & & \\
\hline Yüzeysel Rol Yapma & -.062 & $-.134^{* *}$ & $-.112^{*}$ & $-.110^{*}$ \\
\hline Derinden Rol Yapma & $.154^{*}$ & .063 & $.147^{*}$ & $.138^{*}$ \\
\hline Doğal Duygular & $.327^{*}$ & $.255^{*}$ & $.271^{*}$ & $.324^{*}$ \\
\hline
\end{tabular}

${ }^{*} 0,05$ düzeyinde anlamlıdır. ${ }^{* *} 0,01$ düzeyinde anlamlıdır.

Tablo 7'de görüleceği üzere, duygusal emek gösteriminin yüzeysel rol yapma alt boyutu ile öğretmenlerin psikolojik sözleşmeye uyma düzeyleri arasında anlamlı negatif yönlü ve düşük düzeyde bir ilişki vardır (r:-0.110, $\mathrm{p}<0.05)$. Buna göre, öğretmenlerin yüzeysel rol yapma davranışları arttıkça, psikolojik sözleşmeye uyma düzeyleri azalmaktadır. Yine yüzeysel rol yapma gösterimi ile psikolojik sözleşmenin ekstra performans alt boyutu (r:$0.134, \mathrm{p}<0.01)$ ve sadakat alt boyutu $(\mathrm{r}:-0.112, \mathrm{p}<0.05)$ arasinda anlamlı negatif yönlü ve düşük düzeyde bir ilişki bulunmuştur. Yüzeysel rol yapma gösterimi ile kurumsal gelişme yönelik çaba alt boyutu arasında ise anlamlı bir ilişki bulunmamaktadır. Duygusal emek gösteriminin derinden rol yapma alt boyutu ile öğretmenlerin psikolojik sözleşmeye uymaları arasında anlamlı, pozitif yönlü ve düşük bir ilişki vardır (r:0.138, p<0.01). Öğretmenlerin derinden rol yapma davranışları arttıkça, psikolojik sözleşmeye uyma düzeyleri düşük düzeyde artmaktadır. Derinden rol yapma davranışının psikolojik sözleşmenin alt boyutları ile ilişkisi incelendiğinde ise; kurumsal gelişme yönelik çaba alt boyutu (r:0.154, p<0.01) ve sadakat alt boyutu ile anlamll, pozitif yönlü ve düşük ( $r: 0.147, \mathrm{p}<0.01)$ düzeyde bir ilişki tespit edilmiştir. Derinden rol yapma ile ekstra performans alt boyutu arasında ise anlamlı bir ilişkiye rastlanmamıştır. Öğretmenlerin duygusal emeğin alt boyutlarından olan doğal duygular gösterimi ile psikolojik sözleşmeye uyma düzeyleri arasında istatistiksel olarak anlaml, pozitif yönlü ve orta düzeyde bir ilişki vardır (r:0.324, $\mathrm{p}<0.01$ ). Buna göre, öğretmenlerin doğal duygular gösterimleri arttıkça, psikolojik sözleşmeye uyma düzeyleri orta düzeyde artmaktadır. Bunun yanında, öğretmenlerin doğal duygular davra- 
nışları ile psikolojik sözleşmenin kurumsal gelişme yönelik çaba alt boyutu (r:0.327, $\mathrm{p}<0.01)$ arasında anlamlı pozitif yönlü ve orta düzeyde bir ilişki bulunurken; ekstra performans ( $\mathrm{r}: 0.255, \mathrm{p}<0.01)$ ve sadakat alt boyutu arasinda (r:0.271, p<0.01) anlamlı pozitif yönlü ve düşük düzeyde bir ilişki tespit edilmiştir.

Tablo 8. Öğretmenlerin duygusal emek gösterimine yönelik algılarnnn psikolojik sözleşmeye uyma düzeylerini yordayıp yordamadığına yönelik Regresyon Analizi sonuçlan Yordanan Değişken: Psikolojik Sözleşme

\begin{tabular}{|c|c|c|c|c|c|c|c|}
\hline Yordayıcı Değişken & B & S. Hata & $\beta$ (Beta) & $t$ & $\mathbf{p}$ & Kismi & İkili \\
\hline Sabit & 2.801 & 227 & & 12.360 & .000 & & \\
\hline Yüzeysel Rol Yapma & -.075 & .041 & -.098 & -1.860 & .064 & -.093 & -.087 \\
\hline Derinden Rol Yapma & .081 & .032 & .132 & 2.528 & .012 & .125 & .118 \\
\hline Doğal Duygular & .264 & .046 & .283 & 5.707 & .000 & .274 & .267 \\
\hline $\mathrm{R} 2=.121$ & & & & & & & \\
\hline$F(3-401)=18.356$ & & & & & & & \\
\hline
\end{tabular}

Yapılan regresyon analizi sonucunda, duygusal emeğin alt boyutları olan derinden rol yapma ve doğal duygular davranışlarının öğretmenlerin psikolojik sözleşmeye uymalarına ilişkin algı düzeylerini anlamlı bir anlamlı bir şekilde yordadığı görülmüş̧ür ( $\mathrm{R}=.347, \mathrm{R}^{2}=.121$, $\left.\mathrm{p}<0.05\right)$. Bu bağlamda, duygusal emek gösterimleri olan derinden rol yapma ve doğal duyguların bir arada olduğu bir durumda, öğretmenlerin psikolojik sözleşmeye uymalarına ilişkin algı düzeylerinin yaklaşı \%12'sini açıklayabildiği sonucuna ulaşılmıştır. Yapılan regresyon analizinin $t$ değerleri incelendiğinde; öğretmenlerin derinden rol yapma gösterimindeki bir birimlik artışı psikolojik sözleşmeleri üzerinde .081'lik bir artışa ve doğal duygular gösterilerindeki bir birimlik artı̧ın psikolojik sözleşmeleri üzerinde .264'lük bir artışa neden olduğu anlaşılmaktadır. Bununla birlikte öğretmenlerin duygusal emeğe yönelik yüzeysel rol yapma gösterimlerinin psikolojik sözleşmeleri üzerinde bir etkisinin olmadığı anlaşılmaktadır.

\section{Tartışma, Sonuç Ve Öneriler}

$\mathrm{Bu}$ araştırma, okullarda öğretmenlerin duygusal emek gösterimleri ile psikolojik sözleşmeye uyma düzeyleri arasındaki ilişkiyi belirlemek amaciyla yapılmıştır. Araştırmanın sonuçlarına bakıldığında, öğretmenlerin duygusal emek gösterimlerine yönelik algı düzeylerinin yüzeysel rol yapma alt boyutunda düşük, derinden rol yapma alt boyutunda yüksek ve doğal duygular 
alt boyutunda çok yüksek olduğu görülmektedir. Bu bağlamda, öğretmenlerin okullarda duygusal emek gösterimi için harcadıkları çaba adına en çok samimi duygular davranışına başvurdukları yani muhatabıyla etkileşimi sırasında, o an gerçekte hissettikleri duyguları yansıttıkları anlaşılmaktadır. Ashforth ve Humphrey (1993), çalışmalarında, öğretmenlerin genel olarak samimi duygular sergilemelerinin duygularını içselleştirmelerinin doğal bir sonucu olduğunu ifade etmişlerdir. Elde edilen sonuca yönelik olarak alan yazın incelendiğinde, Göç (2017) okul yöneticilerinin duygusal emek ve iş doyumu ilişkisi üzerine yaptığı çalışmasında okul yöneticilerin en çok samimi duygular davranışını tespit etmiştir. Moran' in (2018) öğretmenlerin duygusal emek davranışları ve yaşam doyum düzeyleri üzeine yaptığı çalışmasında, öğretmenlerin doğal duygular ve derinden rol yapma davranışlarını çoğu zaman, yüzeysel rol yapma davranışını ise bazen sergilediklerini Bulmuştur. Cingöz'ün (2018) öğretmenlerin duygusal emek davranışları ile tükenmişlikleri üzerine gerçekleştirdiği araştırmada ise, öğretmenlerin okullarda duygusal emeğe yönelik olarak en çok doğal duygular, en az yüzeysel rol yapma davranışı sergiledikleri görülmüş̧ür. Yapılan araştırmalar bu araştırmanın sonucu ile benzerlik göstermektedir. Akbaş ve Bostancı da (2016) öğretmenlerin örgütsel politika algıları ve duygusal emek düzeyleri üzerine yaptığı çalışmada, bu çalışmanın sonucundan farklı olarak öğretmenlerin yüzeysel rol yapma, derinden rol yapma ve otomatik duygu düzenleme yani doğal duygular algılarının orta düzeyde olduğunu belirlemişlerdir.

Araştırma sonucunda, öğretmenlerin duygusal emek gösterimlerine yönelik algıları arasında çalıştıkları okul düzeyi değişkeni bakımından, ilkokul, ortaokul ve liselerde görev yapan öğretmenler açışından anlamlı bir farklılık bulunmamıştır. Erken (2018) tarafından yapılan bir çalışmada, bu çalışmaya paralel olarak lise öğretmenlerinin duygusal emeğe yönelik alg1larının görev yaptıkları okul düzeyine göre farklılaşmadı̆̆ı tespit edilmiştir. Begenirbaş (2013) tarafından yapılan araştırmada da bu araştırmayla aynı doğrultuda sonuçlara ulaşıldığı ve okul düzeyi değişkeni açısından öğretmenlerin duygusal emeğe yönelik algılarının farklılaşmadı̆̆ı görülmüştür. Ertürk vd. (2016) tarafından duygusal emek ve psikolojik iyi oluş başlığı altında yapılan bir çalışmada ise, bu çalışmadan elde edilen bulgudan farklı olarak öğretmenlerin duygusal emek düzeylerinin görev yapılan okul düzeyi değişkenine göre anlamlı bir şekilde farklılaştı̆̆ı sonucuna ulaşılmıştır. 
Araştırmada kullanılan diğer demografik verilerden elde edilen sonuçlara göre, cinsiyet değişkeninin öğretmenlerin duygusal emek gösterimleri üzerinde anlamlı farklılıklar oluşturduğu görülmüştür. Oluşan farklar, duygusal emeğin yüzeysel rol yapma ve derinden rol yapma boyutlarında erkek öğretmenler lehinedir. Duygusal emeğin doğal duygular boyutunda ise, öğretmen algıları arasında anlamlı bir farklılık görülmemektedir. $\mathrm{Bu}$ sonuçlar ışı̆̆ında, erkek öğretmenlerin yüzeysel ve derinden rol yapma davranışları vasıtasıyla okullarında duygularını düzenleme yoluna kadın öğretmenlere göre daha çok başvurdukları anlaşılmaktadır. Bu durumun Türk toplumunda, erkeklerin gerçekte hissettikleri duyguları saklamaları yönünde baskın bir anlayışın etkili olmasından dolayı kaynaklandığı düşünülebilir. Alan yazına göre de kadınların erkeklere oranla duygu yönetiminde daha başarılı olduğu ve duygularını içselleştirerek genellikle gerçekte hissettikleri duyguları dışa vurdukları anlaşılmaktadır (Hochschild, 1983; Rafaelli ve Sutton, 1987). Ayrıca araştırmaya ait bu sonuçlar, literatürde öğretmenlerin duygusal emek gösterimleri üzerine yapılan diğer araştırmalara ait sonuçlar ile karşılaştırıldığında; Moran'ın (2018) yaptığı çalışmada bu çalışmaya benzer olarak öğretmenlerin yüzeysel rol yapma algılarının cinsiyet değişkenine göre farklılaşttğ 1 sonucuna ulaşılmıştır. Diğer boyutlarda ise fark bulunmamıştır. Cingöz (2018), yaptığı çalışmada erkek öğretmenlerin kadın öğretmenlere göre yüzeysel ve derinden rol yapma davranışlarını daha çok sergilediklerini; kadın öğretmenlerin de doğal duygular davranışını erkek öğretmenlere göre daha çok sergilediklerini tespit etmiştir. Erken (2018), aynı şekilde öğretmenlerin duygusal emek algılarının cinsiyete göre farklılaşttğı ve liselerde görev yapan erkek öğretmenlerin kadın öğretmenlere oranla yüzeysel ve derinden rol yapma davranışlarına daha çok başvurdukları sonucuna çalışmasında ulaşmıştır. Öğretmenlerin duygusal emek gösterimlerine yönelik görüşleri kıdem yılı değişkeni bakımından ise farklılaşmamaktadır. Araştırmadan elde edilen bu sonuç, yine öğretmenlerin okullarda duygusal emek gösterimleri üzerine gerçekleştirlimiş olan ve kıdem değişkeninin öğretmenlerin duygusal emek algıları üzerinde herhangi bir etkisinin olmadığı sonucuna ulaşılmış ve Moran (2018) tarafından yapılan çalışma ile benzerlik göstermektedir. Yılmaz Daban (2018), de aynı şekilde ortaokul öğretmenlerin dugusal emek algılarının kıdem yılı değişkenine göre farklışamadığını tespit etmiştir. Bu araştırmalardan farklı olarak ise, Beğenirbaş (2013), 21 yıl ve üzeri kıdeme sahip öğretmenlerin 
duygusal emeğe yönelik algılarının daha az kıdeme sahip öğretmenlere oranla daha yüksek olduğu sonucuna ulaşmıştır. Yine bu araştırmada mezuniyet durumuna göre öğretmenlerin duygusal emek gösterimleri arasında farklılık bulunmadığı sonucuna ulaşılmıştır. Dahmaz (2019) tarafından yapılan çalışmada da, bu araştırmaya benzer olarak öğretmenlerin duygusal emek gösterimlerin mezuniyet durumlarına göre farklılaşmadığı sonucuna ulaşılmıştır. Doğan (2019) tarafından öğretmenlerin duygusal emek ve örgütsel yabancılaşma davranışlarının incelendiği çalışmada da aynı şekilde mezuniyet değişkeni açısından öğretmenlerin duygusal emek algılarında farklılık bulunmamıştır. Araştırmada görev yapılan okuldaki öğretmen sayısı ve aynı okulda yaklaşık çalışma süresi değişkenleri bakımından da öğretmenlerin duygusal emek gösterimlerinin anlamlı bir şekilde farklılaşmadığı görülmektedir. Kaya (2009) tarafından özel okul öğretmenlerinin duygusal emek davranışını algılama biçimleri ile iş doyumları ve iş stresleri ve Özgün (2015) tarafından duygusal emek davranışının iş stresine etkisi üzerine yapılan çalışmalarda da, araştırma sonuçlarına benzer olarak aynı okulda yaklaşık çalışma süresi değişkeninin öğretmenlerin duygusal emek gösterimleri üzerinde anlamlı farklılık oluşturmadığı sonucuna ulaşılmıştır.

Araştırmanın diğer değişkeni olan öğretmenlerin psikolojik sözleşmeye uyma düzeylerine ilişkin sonuçlar incelendiğinde ise, öğretmenlerin psikolojik sözleşmeye uymalarına yönelik kurumsal gelişime yönelik çaba alt boyutuna ilişkin algı düzeylerinin çok yüksek, ekstra performans ve sadakat alt boyutlarına ilişkin algı düzeylerinin ise yüksek olduğu görülmektedir. Araştırmada genel olarak psikolojik sözleşmeye uymalarına yönelik öğretmenlerin algılarının yüksek düzeyde olduğu tespit edilmiştir. Öğretmenlerin psikolojik sözleşme ve alt boyutlarına yönelik algılarının yüksek olmasının, onları mesleklerini yüksek düzeyde içselleştirmeleri, mesleklerinin değerini aldıkları ücretin ötesinde görmeleri, mesleklerini sevmeleri ve okul ve öğrencilerinin ihtiyaçlarına daima öncelik vermelerinden kaynaklandığ söylenebilir. Bu araştırmayı destekler nitelikte Koçak (2016) tarafından gerçekleştirilen "Ortaöğretim kurumlarındaki psikolojik sözleşme üzerinde güçlendirici liderlik davranışlarının rolü" adlı çalışmada, öğretmenlerinin psikolojik sözleşmeye uyma davranışlarının yüksek düzeyde olduğunu tespit edilmiştir. Araştırma sonucundan farklı olarak, Çavuş (2018) tarafından okulların dna profilleri ile öğretmenlerin psikolojik sözleşme düzeyleri arasındaki ilişkinin incelendiği ve Çay (2019) tarafından okul yöneticilerinin 
farklılıkları yönetme becerileri ile öğretmenlerin psikolojik sözleşmeye uyma düzeyleri arasındaki ilişkinin incelendiği çalışmalarda, öğretmenlerin psikolojik sözleşmeye uyma algılarının orta düzeyde olduğu tespit edilmiştir.

Araştırma sonucunda, öğretmenlerin psikolojik sözleşmeye uymalarına yönelik algıları arasında çalıştıkları okul düzeyi değişkeni bakımından, psikolojik sözleşmenin ekstra performans alt boyutuna göre çalışılan okul düzeyine göre öğretmen algıları arasında anlamlı bir farklılık bulunmazken, kurumsal gelişime yönelik çaba ve sadakat alt boyutları ile psikolojik sözleşme davranışının toplamında anlamlı farklılıklar tespit edilmiştir. Buna göre, kurumsal gelişime yönelik çaba boyutunda, ilkokul ve liselerde görev yapan öğretmen görüşleri arasında; sadakat alt boyutunda ise hem ilkokul ve ortaokul, hem de ilkokul ve liselerde görev yapan öğretmen görüşleri arasında anlamlı farklılıklar tespit edilmiştir. Bunun yanında öğretmenlerin genel olarak psikolojik sözleşmeye uyma düzeylerinde ilkokul ve liselerde görev yapan öğretmen görüşleri arasında farklılık bulunmaktadır. Bu sonuca göre ilkokul öğretmenlerinin ortaokul ve lise öğretmenlerine göre psikolojik sözleşmeye uyma düzeyleri yüksektir. İlkokullarda görev yapan öğretmenlerinin okullarına karşı oluşturdukları psikolojik sözleşmeyi diğer öğretmen gruplarına oranla daha fazla içselleştirdikleri anlaşılmaktadır. Araştırma sonuçlarına paralel olarak, Koçak (2016) çalışmasında, öğretmenlerin psikolojik sözleşmeye uyma düzeylerine ilişkin algıları üzerinde okul düzeyi değişkeninin anlamlı bir farklılık oluşturduğu sonucuna ulaşmıştır. Benzer şekilde, Doğan (2017) ve Çay (2019) psikolojik sözleşme ve alt boyutları bakımından okul düzeyi değişkenine göre öğretmen görüşleri arasında anlamlı farklılaşmalar tespit etmişleridir. Çavuş (2018) ise, araştırmadan elde edilen bulgulardan farklı olarak, öğretmenlerin psikolojik sözleşmeye uyma düzeylerine ilişkin algıları üzerinde okul düzeyi değişkeninin anlamlı bir farklılık oluşturmadığı sonucuna varmıştır. Sonuç olarak, ilkokul öğretmenlerinin duygusal bağlamda çalıştıkları okullara daha fazla bağlanma eğilimlerinin, onların psikolojik sözleşmeye uyma, okullarının gelişimlerine yönelik çaba ve gayretleri ile sadakatleri üzerindeki etkisi açısından diğer okul düzeylerinde çalışan öğretmenler ile aralarında oluşan farklara sebep olduğu söylenebilir.

Araştırmada diğer demografik değişkenlere yönelik elde edilen sonuçlara göre, araştırmaya katılan öğretmenlerin, psikolojik sözleşmeye uymaları- 
na yönelik görüşlerinde, cinsiyet değişkeni bakımından genel psikolojik sözleşmeye uyma algısında ve kurumsal gelişime yönelik çaba ile ekstra performans alt boyutlarında kadın ve erkek öğretmenler arasında anlamlı bir farklılık ortaya çıkmamışır. Sadakat alt boyutunda ise, kadın öğretmenlerle erkek öğretmenler arasında anlamlı bir fark olduğu tespit edilmiştir. Erkek öğretmenlerin sadakat alt boyutuna yönelik ortalama görüş puanları kadın öğretmenlere göre daha yüksektir. Bu bağlamda, erkek öğretmenlerin okullarına yönelik içsel bağlılıklarının kadın öğretmenlere göre daha yüksek olduğu söylenebilir. Çavuş (2018) tarafından okulların DNA profilleri ile öğretmenlerin psikolojik sözleşme düzeyleri arasındaki ilişkinin incelendiği ve Çay (2019) tarafından okul yöneticilerinin farklılıkları yönetme becerileri ile öğretmenlerin psikolojik sözleşmeye uyma düzeyleri arasındaki ilişkinin incelendiği araştırmalarda, cinsiyet değişkeninin öğretmenlerin psikolojik sözleşmeye uyma algılarını farklılaştırmadığı bulunmuştur. Buna göre, öğretmenlerin kadın ya da erkek olmaları, psikolojik sözleşmeye uyma algılarını anlamlı bir şekilde açıklamamaktadır. Alan yazında, ilgili değişken bakımından farklı sonuçlar da elde edilmiştir. Örneğin, Koçak (2016) tarafından yapılan araştırmada, öğretmenlerin psikolojik sözleşmeye uyma algıları üzerinde cinsiyet değişkeninin anlamlı bir fark oluşturduğu tespit edilmiştir. Genel psikolojik sözleşmeye uyma ve tüm alt boyutlarında kadın öğretmenlerin ortalama görüş puanları erkeklere göre daha düşüktür. Sonuç olarak, toplumda kadınların daha sahiplenici oldukları yönünde oluşmuş genel kanının aksine bir durumun ortaya çıktığını söylemek mümkün olacaktr.

Öğretmenlerin psikolojik sözleşmeye uymalarına yönelik algıları kıdem yılı açısından genel psikolojik sözleşmeye uyma düzeyi ile ekstra performans ve sadakat alt boyutlarında farklılaşmaktadır. Oluşan farklar, ekstra performans alt boyutunda 11-20 yıl kıdeme sahip olan öğretmenler ile 1-10 yıl kıdeme sahip olan öğretmenler arasında iken; sadakat alt boyutunda kıdemi 21 yıl ve üzeri olan öğretmenler ile kıdemi 1-10 yıl olan öğretmenler arasındadır. Psikolojik sözleşmenin toplamında ise, 21 yıl ve üzeri kıdeme sahip öğretmenler ve 11-20 yıl kıdeme sahip öğretmenler ile 1-10 yıl kıdeme sahip öğretmenler arasında anlamlı görüş farkları bulunmaktadır. Bu sonuca göre, öğretmenlerin kıdem yılları arttıkça, psikolojik sözleşmeyi içselleştirme algılarının da doğru orantılı olarak arttı̆ını söylemek mümkün olacaktır. Bunun nedeninin, öğretmenlerin okullarında yaşadıkları deneyim ve 
alışkanlıklar neticesinde, okullarına karşı hissettikleri bağlılıkların artması olarak söylenebilir (Koçak, 2016). Demirkasımoğlu (2012), Doğan (2017) ve Çay (2019) da çalışmalarında kıdem değişkenin öğretmenlerin psikolojik sözleşmeye uyma algilarında anlamlı farklar oluşturduğunu tespit etmişlerdir. Araştırmada, psikolojik sözleşmenin kurumsal gelişime yönelik çaba alt boyutunda ise, gruplar arasında anlamlı bir fark görülmemiştir. Çavuş (2018) da, çalışmasında öğretmenlerin psikolojik sözleşmeye ilişkin algılarının kıdemlerine göre farklılaşmadığını görmüştür.

Araştırmaya katılan öğretmenlerin, psikolojik sözleşmeye uymalarına yönelik algılarında, mezuniyet durumu, görev yaptıkları okuldaki öğretmen sayısı ve aynı okulda yaklaşık çalışma süresi değişkenleri açısından ise, psikolojik sözleşmenin toplamı ve alt boyutlarının tamamında anlamlı herhangi bir farka rastlanamamıştır. Çildir (2008) ve Koçak (2016) da, öğretmenlerin psikolojik sözleşmeye uyma düzeylerine ilişkin algıları ve tüm alt boyutlar üzerinde mezuniyet durumu değişkeninin anlamlı bir fark oluşturmadığını tespit etmiştir Koçak (2016) çalışmasında, okulda görev yapan öğretmen sayısı değişkenin, öğretmenlerin psikolojik sözleşmeye uymaları üzerinde anlamlı farklılık oluşturacak bir etkisinin olduğunu bulmuştur. Yine Doğan (2017) ve Çavuş (2018), öğretmen sayısı ve aynı okulda çalışma süresi değişkenleri bakımından öğretmenlerin psikolojik sözleşme düzeyi algılarında farklılık olmadığını tespit etmişlerdir. Çay (2019) ise, kurumsal gelişime yönelik çaba ve sadakat alt boyutlarında öğretmen görüşlerinin aynı okulda çalışma süresi değişkenine göre farklılaştığını bulmuştur.

Öğretmenlerin duygusal emek gösterimleri ile psikolojik sözleşmeye uyma düzeyleri arasındaki ilişkiye yönelik sonuçlar incelendiğinde ise, öğretmenlerin psikolojik sözleşmeye uymaları ile duygusal emeğin yüzeysel rol yapma gösterimi arasında anlamlı, negatif yönlü ve düşük düzeyde bir ilişki olduğu anlaşılmaktadır. Buna göre, öğretmenlerin yüzeysel rol yapma davranışları arttıkça, psikolojik sözleşmeye uyma düzeyleri azalmaktadır. Yine, öğretmenlerin yüzeysel rol yapma gösterimi ile psikolojik sözleşmenin ekstra performans ve sadakat alt boyutları arasında anlamlı ve negatif yönlü düşük düzeyde bir ilişki bulunmuştur. Öğretmenlerin yüzeysel rol yapma gösterimi ile kurumsal gelişme yönelik çaba alt boyutu arasında ise anlamlı bir ilişki bulunmamaktadır. Bununla birlikte, duygusal emeğin derinden rol yapma gösterimi ile öğretmenlerin psikolojik sözleşmeye uymaları arasında anlamlı, pozitif yönlü düşük düzeyde bir ilişki vardır. Öğretmenlerin derin- 
den rol yapma davranışları arttıkça, psikolojik sözleşmeye uyma düzeyleri de artmaktadır. Derinden rol yapma davranışının psikolojik sözleşmenin alt boyutları ile ilişkisi incelendiğinde ise; kurumsal gelişme yönelik çaba ve sadakat alt boyutu ile anlamlı, pozitif yönlü ve düşük ilişkilere rastlanmaktadır. Derinden rol yapma ile ekstra performans alt boyutu arasında ise anlamlı bir ilişkiye rastlanmamıştır. Öğretmenlerin doğal duygular gösterimi ile psikolojik sözleşmeye uyma düzeyleri arasında anlamlı, pozitif yönlü orta düzeyde bir ilişki vardır. Buna göre, öğretmenlerin doğal duygular gösterimleri arttıkça, psikolojik sözleşmeye uyma düzeyleri orta düzeyde artmaktadır. Bunun yanında öğretmenlerin doğal duygular gösterimleri ile psikolojik sözleşmenin kurumsal gelişme yönelik çaba alt boyutu arasında anlamlı, pozitif yönlü orta düzeyde bir ilişki bulunurken; ekstra performans ve sadakat alt boyutları ile arasında anlaml, pozitif yönlü düşük düzeyde bir ilişki tespit edilmiştir. Xuan ve Park (2012) araştırmalarında, bu araştırmanın sonuçlarına paralel olarak, psikolojik sözleşmenin duygusal emek üzerinde anlamlı bir etkisinin olduğunu bulmuştur (Akt. Sağır ve Ekici, 2020). Elde edilen sonuçlara ve incelenen ilgili araştırmalara göre, öğretmenlerin duygusal emek gösterimleri ile psikolojik sözleşmeye uyma düzeyleri arasında anlamlı bir ilişkinin var olduğu söylenebilir.

Araştırmada son olarak, yapılan regresyon analizi sonucunda, öğretmenlerin duygusal emek gösterimlerinin alt boyutları olan derinden rol yapma ve doğal duyguların öğretmenlerin psikolojik sözleşmeye uymalarına ilişkin alg1 düzeylerini anlamlı bir şekilde yordadığı görülmüsştür. Bununla yanında, öğretmenlerin duygusal emeğe yönelik yüzeysel rol yapma gösterimlerinin psikolojik sözleşmeleri üzerinde herhangi bir etkisinin olmadığı anlaşılmaktadır. Alan yazın incelendiğinde, Sağır ve Ekici (2020) tarafından sanayi işletmeleri üzerine yapılan bir çalı̧̧mada, psikolojik sözleşmenin duygusal emeği \%16 açıklayabildiği görülmüştür. Xuan ve Park (2012, akt. Sağır ve Ekici, 2020), tarafından Çin'deki devlet üniversitelerinde yapılan başka bir araştırmada ise, psikolojik sözleşmenin duygusal emeği yordadığı sonucuna ulaşılmıştır.

Araştırmadan elde edilen sonuçlar özelinde, şu öneriler ileri sürülebilmektedir:

1. Okullarda öğretmenlerin doğru duygu yönetim becerileri kazanabilmeleri adına eğitim faaliyetleri, seminerler ve webinarlar düzenlenerek, bu 
konuda öğretmenlere alanında uzman profesyoneller tarafından gerekli destek sağlanabilir. Bu konuda üniversiteler ile işbirliğine gidilebilir.

2. Öğretmenlerin, okul ortamında psikolojik sözleşmeye yönelik algılarının karşılanması adına doğru okul iklimleri oluşturmak için Milli Eğitim Bakanlığı ve Milli Eğitim Müdürlükleri tarafından gerekli tedbirler alınabilir. Okulların fiziksel imkanları, öğretmenlerin çalışma şartları ve statü olarak öğretmenlik mesleğinin niteliği iyileştirilebilir.

3. Öğretmenlerin duygusal bağlamda en çok etkileşim içerisine girdikleri öğrenci ve veliler ile daha etkin bir iletişim içerisine girebilmeleri adına, öğretmenlere yönelik olarak etkili iletişim becerileri konusunda seminer ve hizmet içi eğitim faaliyetleri ile profesyonel destek sağlanabilir. Bu bağlamda, yine üniversiteler ile protokoller imzalanabilir.

4. Öğretmenlerin duygusal emek gösterimlerinin psikolojik sözleşmelerini etkileyebileceği varsayımından hareketle, öğretmenlerin mesleki beklentilerinin karşılanmasına yönelik öğretmenlik mesleğini değerini artırıcı yasal düzenlemeler yapılabilir.

5. Bu araştırma kamu okullarında yapılmıştır. Özel okullarda ve özel eğitim merkezlerinde çalışan öğretmenlerin duygusal emeğe yönelik alg1ları üzerine çalışmalar yapılabilir.

6. Okullarda eğitim yöneticilerinin de duygusal emeğe yönelik algılarının araştırılması için benzer çalışmalar yapılabilir.

7. Okul düzeyi bazında değerlendirildiğinde, öğretmenlerin psikolojik sözleşmeye uyma düzeyleri farklılaşmaktadır. Okul düzeyine göre öğretmenlerin psikolojik sözleşmeye uymalarında görülen bu farklılı̆̆ının nedenine yönelik nitel bir araştırma yapılabilir. 


\title{
EXTENDED ABSTRACT
}

\section{The Relationship between Teachers' Demonstrations of Emotional Labour and Their Level of Adherence to the Psychological Contract}

\author{
Süleyman Sırrı Aydoğan- Aynur B. Bostanc1 \\ Ministry of National Education, Uşak University
}

Rapid changes in working life have led organizations to care about interpersonal communication and interaction in service delivery. Organizations expect employees to engage in the correct attitude and behaviour required by their service areas, and to spend emotional labour in addition to their physical and mental efforts (Güngör Delen, 2017; Eroğlu, 2014). Schools are among the institutions where face-to-face communication and interaction occur most frequently. For this reason, it requires teachers to constantly regulate their emotions during their work and to make emotional labour as well as mental and physical labor (Tozkoparan and Özgün, 2015). Grandey (2000) defined emotional labour as "the effort spent in the process of organizing both emotions and emotional representations to achieve organizational goals" (Savaş, 2012). Hochschild (1983) states that people express the behaviours they exhibit during their emotional management in two ways: surface acting and deep acting (Mavi, 2015; Ünler Öz, 2007). Ashforth and Humphrey (1993) acknowledge these two dimensions of emotional labour and have added the genuine emotions dimension, in other words, the employee's sincere behaviour without any effort. Employees have some expectations in return for the physical, mental and emotional efforts they spend in the organization, regarding the duties and responsibilities that the organizations they work with expect them to do. This set of expectations created by both the organization and the employee mutually is called the psychological contract (Özdaşlı and Çelikkol, 2012; Doğan and Demiral, 2007). Psychological contract is defined as the mutual exchange of unwritten expectations in employee and employer relations (Karcığlu andTürker, 2010). Teachers have some expectations from their institutions as a result of their emotional efforts to show their institutions' expectations from them. The whole of ex- 
pectations that teachers have towards their institutions is the basis of their psychological contracts against the institution (Koçak, 2016). The level of teachers' adherence to their psychological contracts is important for schools to achieve their goals. In this sense, it can be stated by the Ministry of National Education that teachers' demonstrations of emotional labour will be more attached to their work and will enable them to maintain their psychological contracts. In this sense, it can be stated that teachers' demonstrations of emotional labour which is valued by the Ministry of National Education will be more attached them to their work and will enable them to maintain their psychological contracts. Because, as a result of the emotional labour demonstrations of employees, achieving their goals and thus success in their work has a positive effect on their job satisfaction, commitment to their profession, motivation, performance and job satisfaction (Begenirbaş and Yalçın, 2012; Güngör Delen, 2017). Otherwise, it can be said that emotional labour may lead to some negative consequences on teachers such as burnout, low performance, depersonalization and alienation, which are widely mentioned in the literature (Isenbarger and Zembylas, 2006). With this research, it is planned to raise awareness among education administrators about the expectations of teachers, who are the cornerstone of education, from their institutions in response to their demonstrations of emotional labour, and the reforms that have been attempted by the Ministry of Education in recent years in the field of education. For this purpose, it is aimed to investigate the relationship between teachers' demonstrations of emotional labour and their level of adherence to the psychological contract. In line with the purpose of the study, answers to the following questions are sought in the study.

1. What is the level of teachers' general emotional labour demonstrations?

2. Do teachers' demonstrations of emotional labour differ according to their school level, gender, professional seniority, graduation status, the number of teachers in the school where they work, and the duration of the same school?

3. What is the teachers' level of adherence to the psychological contract?

4. Does teachers' level of adherence to the psychological contract differ according to their school level, gender, professional seniority, graduation status, the number of teachers in the school they work, and the duration of work in the same school? 
5. Is there a significant relationship between teachers' demonstrations of emotional labour and their level of adherence to the psychological contract?

6. Do teachers' demonstrations of emotional labour explicate their level of adherence to the psychological contract?

Since this research is conducted to determine the relationship between teachers' demonstrations of emotional labour and their level of adherence to the psychological contract they formed against the school they work, it is carried out using the relational survey model. The population of the research is the teachers who work in official primary, secondary and high schools in the districts of Gediz, Simav, Şaphane and Çavdarhisar in Kütahya in the 2019-2020 academic year. The population of the research consists of 1502 teachers. The theoretical sample size chart is used to determine the sample. The sample of the study consists of 405 teachers who are selected with convenience sampling method and working in the mentioned districts. In the study, "Emotional Labour Scale" is used to determine teachers' demonstrations of emotional labour, and "Level of Adherence to the Psychological Contract Scale" is used to determine their level of adherence to the psychological contract. In order to determine the analysis to be applied to the data obtained in the study, the skewness and kurtosis coefficients are examined for whether the data was normally distributed and it is understood that the data were normally distributed. For the statistical analysis of the data, Confirmatory Factor Analysis, Arithmetic Mean, One-Way Analysis of Variance (ANOVA), Independent Samples t-Test, Pearson Product-Moment Coefficient and Multiple Regression Analysis were used.

This study is conducted to determine the relationship between teachers' display of emotional labour and their level of compliance with psychological contract. According to the results of the research, it is seen that the perception levels of teachers towards the demonstrations of emotional labour are low in the surface acting sub-dimension, high in the deep acting subdimension, and very high in the genuine emotions sub-dimension. In this context, it is understood that teachers mostly resort to the behaviour of sincere feelings in the name of their efforts to display emotional labour in schools, that is, they reflect the feelings they actually feel at that moment during their interaction with their interlocutor. According to the research, no differentiation could be found between the perceptions of the teachers 
regarding emotional labour display according to the school level they work at. Looking at the results obtained from other demographic data in the study, it is seen that the gender variable created significant differences on teachers' emotional labour demonstrations. The differences that occur are in favour of male teachers in the surface and deep acting dimensions of emotional labour. In the genuine emotions dimension of emotional labour, there is no significant difference between male and female teachers' perceptions. Teachers' views on emotional labour demonstrations do not differ according to seniority, graduation status and approximate duration of work at the same school.

When the results of teachers' level of adherence to the psychological contract that is another variable of the study, are examined, it is seen that the perception levels of teachers regarding the sub-dimension of effort towards institutional development for compliance with the psychological contract are very high, and the perception levels of the sub-dimensions of extra performance and loyalty are high. In the study, it is understood that teacher perceptions towards the level of adherence to the psychological contract are also at a high level. As a result of the research, there is no significant difference between teachers working in primary, secondary and high schools according to the extra performance sub-dimension of the psychological contract in terms of the school level variable they work in between the perceptions of teachers regarding compliance with the psychological contract. But significant differences were determined in the sub-dimensions of effort towards institutional development, loyalty and in the sum of psychological contract behaviour. According to this result, primary school teachers' level of adherence to the psychological contract is higher than secondary and high school teachers. According to the results obtained for other demographic variables in the study, no significant difference emerged between male and female teachers in the general psychological contract level and sub-dimensions, effort for institutional development and extra performance in terms of gender variable. In the loyalty sub-dimension, a significant difference was found between female teachers and male teachers. Male teachers' average opinion scores on loyalty sub-dimension are higher than female teachers. Teachers' level of adherence to the psychological contract in terms of years of seniority differs in the sub-dimensions of extra performance and loyalty and in general. According to this result, it is possible to say that as 
the years of seniority of teachers increase, their level of adherence to the psychological contract increases in direct proportion. The level of adherence to the psychological contract in the total and sub-dimensions of the teachers participating in the study does not differ in terms of graduation status, the number of teachers at the school they work, and the approximate duration of work in the same school. When examining the results regarding the relationship between teachers 'demonstrations of emotional labour and their level of adherence to the psychological contract, it is understood that there is a significant, negative and low level relationship between the surface acting dimension of emotional labour and the teachers' level of adherence to the psychological contract. In addition, there is a statistically significant, positive and low level relationship between teachers ' deep acting from their emotional labour demonstrations and teachers' level of adherence to the psychological contract. There is a statistically significant, positive and medium level relationship between teachers' display of genuine emotions and their level of adherence to the psychological contract. Finally, it was seen that deep acting and genuine emotions, which are sub-dimensions of teachers' emotional labour demonstrations, significantly explicate teachers' perception levels of adherence to the psychological contract. It is understood that teachers' surface acting demonstrations for emotional labour do not have any effect on their psychological contracts. According to the results of the research, it can be suggested to make legal arrangements to increase the value of the teaching profession in order to meet the teachers' professional expectations, since the emotional labour demonstrations of the teachers affect their psychological contract adherence levels.

\section{Kaynakça / References}

Akbaş, A. ve Bostancı, A. B. (2019). Öğretmenlerin örgütsel politika algıları ile duygusal emek düzeyleri arasındaki ilişki. Uşak Üniversitesi Ĕ̆itim Araştırmalan Dergisi, 5(3), 43-60.

Akyüz, N. E. (2014). Psikolojik sözleşme ve örgütsel özdeşleşme ilişkisi: Ankara PTT Başmü̈dürlü̈̆̈̈ örneği. Yayımlanmamış Yüksek Lisans Tezi. Aksaray Üniversitesi, Sosyal Bilimler Enstitüsü, Aksaray.

Alemdar, M. (2019). Sosyal sermayenin eğitim-öğretim süreçlerine yansımast: Duygusal okuryazarlk ve duygusal emek bağlamı. Yayınlanmamış Doktora Tezi. Eskişehir Osmangazi Üniversitesi, Eğitim Bilimleri Enstitüsü, Eskişehir. 
Alev, S. (2018). Öğretmenlerin genel öz yeterlilik alglan ile duygusal emek davranıslan arasındaki ilişkinin incelenmesi: İzlenim yönetimi taktiklerinin aracilk rolü. Yayınlanmamış Doktora Tezi. Gaziantep Üniversitesi, Eğitim Bilimleri Enstitüsü, Gaziantep.

Ashforth, B. E. ve Humphrey, R. H. (1993). Emotional labor in service roles: The influence of identity. Academy Of Management Review, 18(1), 88-115.

Balcı, A. (2011). Sosyal bilimlerde araştrma yöntem, teknik ve ilkeler. Ankara: Pegem Yayıncilik.

Basım, H. N. ve Beğenirbaş, M. (2012). Çalışma yaşamında duygusal emek: Bir ölçek uyarlama çalışması. Yönetim ve Ekonomi, 19(1), 77-90.

Basım, H. N., Beğenirbaş, M. ve Yalçın, R. C. (2013). Effects of teacher personalities on emotional exhaustion: mediating role of emotional labor. Educational Sciences: Theory and Practice, 13(3), 1488-1496.

Beğenirbaş, M. ve Meydan, C. H. (2012). Duygusal emeğin örgütsel vatandaşlık davranışıyla ilişkisi: öğretmenler üzerinde bir araştırma. Gazi Üniversitesi İktisadi ve İdari Bilimler Fakültesi Dergisi, 14(3), 159-181.

Beğenirbaş, M. ve Yalçın, R. C. (2012). Hizmetkâr liderlik algisının duygusal emek üzerine etkileri: hizmet çalışanları üzerinde bir araştırma. Savunma Bilimleri Dergisi, 19(37), 159-194.

Beğenirbaş, M. (2013). Kişiliğin öğretme stillerine etkisinde duygusal emek ve tükenmişlĭgin aracllk rolü: Öğretmenler üzerinde bir araştırma. Yayınlanmamış Doktora Tezi Kara Harp Okulu Savunma Bilimleri Enstitüsü, Ankara.

Bekaroğlu, A. (2011). Kurum içi adaletin şartl değişken olarak psikolojik sözleşme ihlaline verilen tepkiler üzerine etkisi. Yayınlanmamış Yüksek Lisans Tezi. Marmara Üniversitesi, Sosyal Bilimler Enstitüsü, İstanbul.

Bıyık, Y. ve Aydoğan, A. (2014). Duygusal emek ile örgütsel vatandaşlık davranı̧̧ı ilişkisi: Bir araştırma. Gazi Üniversitesi İktisadi ve İdari Bilimler Fakültesi Dergisi, 16(3), 159-180.

Büyüköztürk, Ş. (2012). Sosyal bilimler için veri analizi el kitabı (4. Baskı). Ankara: Pegem Yayınları.

Ceylan, A. K. (2017). Öğretmenlerin duygusal emeklerinin sosyo-demografik değişkenler yönünden özellikleri: Batman ili araştırması. Batman Üniversitesi Yaşam Bilimleri Dergisi, 7(2), 122-132.

Cihangiroğlu, N. ve Şahin, B. (2010). Organizasyonlarda önemli bir fenomen: Psikolojik sözleşme. Uluslararası Yönetim İktisat ve İşletme Dergisi, 6(11), 1-16. 
Cingöz, E. (2018). Öğretmenlerinin duygusal emek ile tükenmişlik düzeyleri arasındaki ilişkinin incelenmesi Yayımlanmamış Yükseklisans Tezi. Osmangazi Üniversitesi, Sosyal Bilimler Enstitüsü, Eskişehir.

Cribbs, A. J. (2015). Emotional labor and conflict in schools: Teacher perceptions of the emotional display rules necessary for negative teacher-student interactions.Unpublished doctoral dissertation, University of Pittsburgh, Pittsburgh, PA.

Çağlayan, B. (2016). Psikolojik sözleşme algısınn örgütsel bağhliğga etkisi: Devlet okullarnda görev yapan ilkokul ve ortaokul öğretmenleri üzerinde bir uygulama Yayımlanmamış Yükseklisans Tezi. Çankaya Üniversitesi, Sosyal Bilimler Enstitüsü, Ankara.

Çaldağ, M. A. (2010). Duygusal emek davranışlarının sağlık çalı̧̧anlarında iş sonuçlarnna etkileri.Yayınlanmamış Doktora Tezi. Selçuk Üniversitesi, Sosyal Bilimleri Enstitüsü, Konya.

Çavuş, E. (2018). Okullarn DNA profilleri ile öğretmenlerin psikolojik sözleşmeleri arasındaki ilişki. Yayınlanmamış Yükseklisans Tezi, Uşak Üniversitesi, Sosyal Bilimler Enstitüsü, Uşak.

Çay, A. Y. (2019). Okul yöneticilerinin farklllklan yönetme becerileri ile öğretmenlerin psikolojik sözleşmeye uyma düzeyleri arasındaki ilişki Yayınlanmamış Yükseklisans Tezi, Uşak Üniversitesi, Sosyal Bilimler Enstitüsü, Uşak.

Çekiç, O. ve Göç, A. (2016). İlkokulda görev yapan sinf öğretmenleri ile liselerde görev yapan branş ögrretmenlerinin duygusal emek düzeyleri. VII. Uluslararası Eğitim Araştırmalan Kongresi, Çanakkale,

Çildir, T. K. (2008). Ankara ilköğretim okullarnnda çalı̧an yönetici ve öğretmenlerin takas kuramının algılanmasına ilişkin algıları. Yayınlanmamış Doktora Tezi, Ankara Üniversitesi, Eğitim Bilimleri Enstitüsü, Ankara.

Çukur, C. Ş. (2009). Öğretmenlerde duygusal işçilik ölçeği geliştirme: Geçerlik ve güvenirlik çalışması. Psychology, 33(6), 626-633.

Dahmaz, A. (2019). Sinnf öğretmenlerinin örgütsel adalet algilarn ile duygusal emek düzeyleri arasındaki ilişkinin incelenmesi. Yayımlanmamış Yükseklisans Tezi, Abant İzzet Baysal Üniversitesi, Eğitim Bilimleri Enstitüsü, Bolu.

Deliveli, K. (2019). Eğitim örgütleri açısından duygusal emeğin önemi. Toplum Bilimleri Dergisi, 25, 190-215.

Demircan, P. (2016). İş-aile çatışması - Duygusal emek ilişkisinde lider desteğinin rolü: eğitim üzerine bir araştırma. Yayımlanmamış Yüksek Lisans Tezi, Süleyman Demirel Üniversitesi, Isparta. 
Diefendorff, J. M. ve Gosserand, R. H. (2003). Understanding the emotional labor process: A control theory perspective. Journal of Organizational Behavior, 24(8), 945-959.

Diefendorff, J. M., Croyle, M. H. ve Gosserand, R. H. (2005). The dimensionality and antecedents of emotional labor strategies. Journal of vocational behavior, 66(2), 339-357.

Doğan, S. ve Demiral, Ö. (2007). The role and importance of emotional intelligence on institutions' success. Management and Economy, 14(1), 209-230.

Doğan Ö. (2017). Okullarn sosyal sermaye düzeyleri ile öğretmenlerin psikolojik sözleşmeleri arasındaki ilişki. Yayımlanmamış Yüksek Lisans Tezi. Uşak Üniversitesi, Sosyal Bilimler Enstitüsü, Uşak.

Doğan M. (2019). Öğretmenlerin duygusal emek ve örgütsel yabancilaşma davranışlarınn incelenmesi. Yayımlanmamış Yüksek Lisans Tezi. Ege Üniversitesi, Sosyal Bilimler Enstitüsü, İzmir.

Dönmez, N. (2015). Okullarda görev yapan öğretmenlerin psikolojik sözleşme düzeyleri ile örgütsel bağhllkklarn arasındaki ilişki. Yayımlanmamış Yüksek Lisans Tezi, Uşak Üniversitesi, Sosyal Bilimler Enstitüsü, Uşak.

Erken, S. A. (2018). Lise öğretmenlerinin duygusal emek davranıslarn ile tükenmişlik düzeyleri arasındaki ilişkinin incelenmesi. Yayımlanmamış Yükseklisans Tezi, Marmara Üniversitesi, Sosyal Bilimler Enstitüsü, İstanbul.

Eroğlu, Ş. G. (2014). Örgütlerde duygusal emek ve tükenmişlik ilişkisi üzerine bir araştırma. Pamukkale University Journal of Social Sciences Institute/Pamukkale Üniversitesi Sosyal Bilimler Enstitüsü Dergisi, 19, 147-160.

Ertürk, A., Kara, S. B. K. ve Güneş, D. Z. (2016). Duygusal emek ve psikolojik iyi oluş: Bir yordayıcı olarak yönetsel destek algısı. Abant İzzet Baysal Üniversitesi Eğitim Fakültesi Dergisi, 16(4),1723-1744.

George, C. (2010). Psychological Contract: Managing and Developing Professional Groups. Maidenhead, G.B.: Open University Press. Chapter 1.

Göç, A. (2017). Okul Yöneticilerinin duygusal emek ve iş doyumu arasındaki ilişkiye dair bir inceleme. Yayımlanmamış Yüksek Lisans Tezi. Çanakkale Onsekiz Mart Üniversitesi, Eğitim Bilimleri Enstitüsü, Çanakkale.

Güney, S. (2017). Örgütsel dauranış (4. Basım). Ankara: Nobel Yayıncllk.

Güngör Delen, M. (2017). Duygusal emek ve tinsel emek. Türkmen Kitabevi, İstanbul.

Hargreaves, A. (2001). The emotional geographies of teachers' relations with colleagues. International Journal Of Educational Research, 35(5), 503-527.

Hochschild, A. R. (1983). The managed heart: The commercialization of human felling. University of California Press. 
Hoşgörür, T. ve Yorulmaz, Y. I. (2015). The relationship between teachers' leadership behaviours and emotional labour: Ögretmenlerin liderlik davranışlanı ile duygusal emekleri arasındaki ilişki. Online Submission, 5(2), 165-190.

Isenbarger, L. ve Zembylas, M. (2006). The emotional labour of caring in teaching. Teaching and Teacher Education, 22(1), 120-134.

Kalayci, Ş. (2009). SPSS uygulamalı çok değişkenli istatistik teknikleri. İstanbul: Asil Yayın Dağıtım Ltd.Sti.

Karasar, N. (2005). Bilimsel araştırma yöntemi (17. Baskı). Ankara: Nobel yayın dağıtım, 81-83.

Karcıoğlu, F. ve Türker, E. (2010). Psikolojik sözleşme ile örgütsel bağlllık ilişkisi: Sağlik çalsşanları üzerine bir uygulama. Atatürk Üniversitesi İktisadi ve İdari Bilimler Dergisi, 24(2), 121-140.

Kaya, E. (2009). Özel okul öğretmenlerinin duygusal emek davranışın alğlama biçimleri ile iş doyumlar ve iş stresleri arasındaki ilişki. Yayımlanmamış Yüksek Lisans Tezi, Maltepe Üniversitesi, Sosyal Bilimler Enstitüsü, İstanbul.

Keleş, Y. (2014). Örgütsel adaletin duygusal emek üzerindeki etkisi: antalya'daki beş yldizl otel işletmelerinde bir araştırma. Yayınlanmamış Doktora Tezi, Gazi Üniversitesi, Eğitim Bilimleri Enstitüsü, Turizm İşletmeciliği Ana Bilim Dalı, Ankara.

Kural, E. (2016). Psychometric properties of the emotional labor scale in a Turkish sample of school administrators. Eurasian Journal of Educational Research, 63, 71-88, http://dx.doi.org/10.14689/ejer.2016.63.5.

Koçak S. (2016). Ortaöğretim kurumlarnndaki psikolojik sözleşme üzerinde güçlendirici liderlik davranışlarmın rolü. Yayınlanmamış Doktora Tezi. Hacettepe Üniversitesi, Eğitim Bilimleri Enstitüsü, Ankara.

Kruml, S. M. ve Geddes, D. (2000). Exploring the dimensions of emotional labor: The heart of Hochschild's work. Management Communication Quarter$l y, 14(1), 8-49$.

Mavi, D. (2015). Öğretmen görüşlerine göre duygusal emek, iş özellikleri ve iş akışı arasındaki ilişki. Yayımlanmamış Yüksek Lisans Tezi. Zirve Üniversitesi, Sosyal Bilimler Enstitüsü, Gaziantep.

Mimaroğlu, H. (2008). Psikolojik sözleşmenin personelin tutum ve davranışlarma etkileri: Tibbi satış temsilcileri üzerinde bir araştırma. Yayınlanmamış Doktora Tezi. Çukurova Üniversitesi, Sosyal Bilimler Enstitüsü, Adana.

Moran, C. (2018). İlköğretim kurumlarnndaki öğretmenlerin duygusal emek davranışlar ile yaşam doyum düzeyleri arasındaki ilişki. Yayınlanmamış yüksek lisans tezi, Çanakkale Onsekiz Mart Üniversitesi, Çanakkale. 
Morrison, E. W. ve Robinson, S. L. (1997). When employees feel betrayed: A model of how psychological contract violation develops. Academy of management Review, 22(1), 226-256.

Oral, A. G. L. ve Köse S. (2011). Hekimlerin duygusal emek kullanımı ile iş doyumu ve tükenmişlik düzeyleri arasındaki ilişkiler üzerine bir araştrma. Süleyman Demirel Üniversitesi İktisadi ve İdari Bilimler Fakültesi Dergisi, 16(2), 463-492.

Önal G. (2019). Öğretmenlerin duygusal emek düzeyleri ile örgütsel vatandaşlı davranışları arasındaki ilişki. Yayımlanmamış Yüksek Lisans Tezi, Marmara Üniversitesi, Sabahattin Zaim Üniversitesi, Sosyal Bilimler Enstitüsü, İstanbul.

Öz, E. Ü. (2007). Duygusal emek davranışlarmnn çalışanlarm iş sonuçlarına etkisi. İstanbul: Beta Basım Yayım Dağıtım A. Ş.

Özdaşlı, K. ve Çelikkol, Ö. (2012). Psikolojik sözleşme: Kavramsal çerçeve ve bir içerik analizi Mehmet Akif Ersoy Üniversitesi, Sosyal Bilimler Enstitüsü Dergisi, $4(7), 14-154$.

Özgün, A. ve Tozkoparan, G. (2015). Duygusal emek davranışının iş stresine etkisi: Eğitim sektöründe bir araşttrma. Örgütsel Davranış Kongresi, 58-62.

Polatkan, N. N. (2016). Ortaokul öğretmenlerinin duygusal emek davranışlan ile iş doyumları arasındaki ilişki. Yayımlanmamış Yüksek Lisans Tezi, Adnan Menderes Üniversitesi, Sosyal Bilimler Enstitüsü, Aydın.

Rafaeli, A. ve Sutton, R. I. (1987). Expression of emotion as part of the work role. Academy of management review, 12(1), 23-37.

Robinson, S. L. (1996). Trust and breach of the psychological contract. Administrative Science Quarterly, 41 (4), 574-599.

Rousseau, D. M. ve McLean Parks, J. (1993). The contracts of individuals and organizations. Research In Organizational Behavior, 15, 41-43.

Rousseau, D. M. (1998). The problem of the psychological contract considered. Journal Of Organizational Behavior, 19, 665-671.

Sağır, Ö. Ü. M. ve Ekici, F. (2020). Örgütlerde psikolojik sözleşme ve duygusal emek: sanayi işletmeleri örneği. 5. İKSAD uluslararast sosyal bilimler kongresi, 106.

Savaş, A. C. (2012). Ilköğretim okul müdürlerinin duygusal zekâ ve duygusal emek yeterliklerinin öğretmenlerin iş doyumuna etkisi. Yayınlanmamış Doktora Tezi. Gaziantep Üniversitesi, Eğitim Bilimleri Enstitüsü, Gaziantep.

Seçer, İ. (2013). SPSS ve LISREL ile pratik veri analizi. Ankara: Anı Yayıncillk.

TEDMEM. (2014). Öğretmen gözüyle öğretmenlik mesleği (Türk Eğitim Derneği Rapor No. 3). Ankara. 
Truta, C. (2014). Emotional labor and motivation in teachers. Procedia-Social and Behavioral Sciences, 127, 791-795.

Turnley, W. H. ve Feldman, D. C. (2000). Re-examining the effects of psychological contract violations: unmet expectations and job dissatisfaction as mediators. Journal of organizational behavior, 21(1), 25-42.

Winograd, K. (2003). The Functions of teacher emotions: the good, the bad, and the ugly. Teachers College Record, 105(9), 1641-1673.

Yılmaz, K. ve Altınkurt, Y. (2012). Özel dershane öğretmenlerinin psikolojik sözleşmeleri. EJEDLIS Elektronik Ĕ̆itim Bilimleri Dergisi, 2(1), 11-22.

Yilmaz, K., Altınkurt, Y., Güner, M. ve Sen, B. (2015). The relationship between teachers' emotional labor and burnout level. Eurasian Journal of Educational Research, 5, 75-90.

Yılmaz Daban, B. (2018). Ortaokul öğretmenlerinin duygusal emek ile tükenmişlik düzeyleri arasındaki ilişkinin incelenmesi. Yayınlanmamış Doktora Tezi, Recep Tayyip Erdoğan Üniversitesi, Sosyal Bilimler Enstitüsü, Rize.

Yin, H. B., Lee, J. C. K., Jin, Y. L. ve Zhang, Z. H. (2013). Exploring the Relationship among Teachers' Emotional Intelligence, Emotional Labor Strategies and Teaching Satisfaction. Teaching and Teacher Education, 35, 137-145.

Zembylas, M. (2004). The emotional characteristics of teaching: An ethnographic study of one teacher. Teaching and Teacher Education, 20(2), 185-201.

\section{Kaynakça Bilgisi / Citation Information}

Aydoğan, S. S. ve Bostancı, A. B. (2021). Öğretmenlerin duygusal emek gösterimleri ile psikolojik sözleşmeye uyma düzeyleri arasındaki ilişki. OPUS-Uluslararası Toplum Araştırmaları Dergisi, 17(36),2637-2674. DOI: 10.26466/opus.860699 